Crônicas da ATUALIdAde do direito internacional .................................................. 2

I. Dossiê Temático: Direito Transnacional .........................................................15

EDITORIAL: O Direito Transnacional - Circulação de normas e relações jurídicas transnacionais .......16 Priscila Pereira de Andrade

A emergênCia do direito transnacional ambiental .............................................18 Priscila Pereira de Andrade

Desafíos y RESPUESTAS TRANSNACIONALES FRENTE A LOS CRÍMENES AMBIENTALES ...............30 Rosmerlin Estupiñan-Silva

DiREITO TRANSNACIONAL E MUdANÇAS CLIMÁTICAS .50 Géraud de Lassus Saint-Geniès

Especies en movimiento: la Convención sobre el Comercio Internacional de Especies Amenazadas de Fauna y Flora Silvestres como espacio de “Encuentro” de discursos, ACTORES Y ESTRATEGIAS EN EL DERECHO AMBIENTAL TRASNACIONAL

María Valeria Berros e Dabel Leandro Franco

El carácter transnacional del Sistema comunitario de ECogestion « Eco-ManageMENT AND Audit SCHEME » (EMAS) DENTRo de LA UE y MÁs ALlÁ DE SUS Fronteras ......72 Adélie Pomade

O CONCEITO DE CONDUTA EMPRESARIAL RESPONSÁVEL À LUZ DOS ORDENAMENTOS JURÍDICOS BRASILEIRO, INTERNACIONAL E TRANSNACIONAL

Gabriel Webber Ziero

ARBITRAGEM NO DIREITO TRIBUTÁRIO INTERNACIONAL E NO DIREITO INTERNACIONAL DOS INVESTIMENTOS: UMA MANIFESTAÇÃO DO DIREITO TRANSNACIONAL

Vivian Daniele Rocha Gabriel 
O DIREITO TRIBUTÁRIO SOB UMA PERSPECTIVA TRANSNACIONAL

Franciele de Simas Estrela Borges

As Características do Direito Transnacional como Metodologia: Análise sob o enfoQue dos Aspectos Processuais da Arbitragem 126

Flávia Foz Mange

O DIREITO TRANSNACIONAL (“GLOBAL LAW") E A CRISE DE PARADIGMA DO ESTADO-CENTRISMO: É POSSÍVEL CONCEBER UMA ORDEM JURÍDICA TRANSNACIONAL? ...................................... 146

Luiza Nogueira Barbosa e Valesca Raizer Borges Moschen

TransPorte AÉREO E DIREITO TRANSNACIONAL: DA CONVERGÊNCIA À UNIFORMIDADE 160 Mickael R. Viglino

Outros Artigos. 175

O Fundo Monetário Internacional e a proteção dos direitos humanos: uma análise DO PROGRAMA DE CRESCIMENTO E REDUÇÃO DA POBREZA NO HAITI 177

Pablo Henrique Hubner de Lanna Costa e Carlos Alberto Simões de Tomaz

Um estranho no ninho? Padrões privados no Acordo de Barreiras Técnicas ao CoMÉRCIO DA OMC 192

Michelle Ratton Sanchez Badin e Marina Yoshimi Takitani

Os benefícios tributários do programa Inovar-Auto e os princípios da Nação Mais Favorecida e do Tratamento Nacional: uma análise dos argumentos dos Painéis atualmente em Curso contra o Brasil no Órgão de SoluÇão de Controvérsias da OMC . 211 Eric Moraes Castro e Silva

A ERA DA HUMANIDADE: REFLEXões PARA A HISTÓRIA DO DIREITO INTERNACIONAL 236 Henrique Weil Afonso

Precedentes vinculantes nos Estados Unidos da América e no direito brasileiro: Um ESTUDO COMPARADO 264

Patrícia Perrone Campos Mello 
IL DIRITTO AMBIENTALE SECONDO L'OTTICA DEL DIRITTO COSTITUZIONALE POSITIVO E LA RESPONSABILITÀ PER DANNI ALL'AMBIENTE NEL DIRITTO COMUNITARIO: LO STATO DELL'ARTE DEL DIRITTO AMBIENTALE COSTITUZIONALE E COMUNITARIO 287

Elcio Nacur Rezende

DA DESCONSIDERAÇÃo DA PERSONALIDADE JURÍDICA NAS RELAÇÕES CONSUMEIRISTAS BRASILEIRAS: ANÁLISE À LUZ DAS TEORIAS CLÁSSICAS

Daniel Amin Ferraz e Marcus Vinicius Silveira de Sá

ANALYSIS OF ADVANTAGES AND DISADVANTAGES OF FORUMS PRESCRIBED UNDER THE UNCLOS AND STATE PRACTICE: THE WAY AHEAD FOR INDIA ......................................................319

Vinai Kumar Singh

Do governo POR LEIS À governanÇA POR NúMERos: breve anÁlise do Trade in SERVICE AgreEMENT (TISA) ...............................................................................338 Jânia Maria Lopes Saldanha, Rafaela da Cruz Mello e Têmis Limberger

As DIRETIVAS EUROPEIAS COMO NORMA REGULADORA DO DIREITO ADMINISTRATIVO GLOBAL ..356 Alice Rocha da Silva e Ruth Maria Pereira dos Santos

O desenVolvimento da POlítica AGRícola COMUM dA UNião EUROPEIA 375 Tatiana de A. F. R. Cardoso Squeff

A imunidade de Jurisdição das organizaÇões internacionais FaCE AO Direito de aCESSO À JUSTIÇA 391

Fernanda Araújo Kallás e Caetano

O DIREITO INTERNACIONAL ENTRE O DEVER ÉTICO E A AÇÃo POLÍ́TICA: OS FUNDAMENTOS DE UM DEVER DE COOPERAÇÃO INTERNACIONAL NA FILOSOFIA POLÍTICA DE IMMANUEL KANT .405 Ademar Junior Pozzatti

EXTENSÃo E FRAGMENTAÇÃo NO CONTEXTO DA JURISDIÇÃO PENAL INTERNACIONAL .423 Marcus Vinícius Xavier de Oliveira

A DEFINiÇÃo JURÍdiCA DA "COMUNIDADE" .444 Nitish Monebhurrun, Michelle Lucas Cardoso Balbino, Fernanda Castelo Branco Araujo, Othon Pantoja, Míara Bogo Bruno e Cândida Dettenborn Nóbrega 
Comparative Study on Chinese Local Legislation of Science and Technology ProGRESS

LI Xiaoming e LI Yihan

O CONTROLE PENAL DO TRÁFICO DE PESSOAS: CONSTRUÇÃO JURÍDICA, INTERAÇÕES ORGANIZACIONAIS E COOPERAÇÃO INTERNACIONAL

Bruno Amaral Machado e Priscilla Brito Silva Vieira

Desativismo judicial: a extradição Battisti no Supremo Tribunal Federal .505 Francisco Rezek e Israel Paulino

A decisão norte-americana do Caso Myriad: novos paradigmas para a Proteção patenTÁRIA DO CÓDIGO GENÉTICO HUMANO E BIOTECNOLOGIA 514 José Carlos Vaz e Dias e Clarisse De La Cerda 


\section{Extensão e fragmentação no contexto da jurisdição penal internacional*}

\section{Extension and Fragmentation in the Context of International Criminal Jurisdiction}

Marcus Vinícius Xavier de Oliveira**

\section{Resumo}

Neste trabalho são abordados os problemas inerentes à jurisdição penal internacional no contexto do Direito Internacional contemporâneo, duplamente caracterizado pela extensão e pela fragmentação. No primeiro tópico, é discutido o tema relativo à ambiguidade do conceito de jurisdição, para, logo após, enfrentarem-se os principais temas conceitual, institucional e histórico do desenvolvimento da jurisdição penal internacional. Por fim, são abordados os problemas da extensão e da fragmentação em referido contexto. A título de conclusão provisória, assenta-se a resposta a ditos problemas na necessidade de se implementar e aperfeiçoar a cooperação penal internacional entre os Estados.

Palavras-chave: Jurisdição Penal Internacional. Extensão. Fragmentação. Cooperação Internacional em Matéria Penal.

\section{Abstract}

In this paper we discuss the problems of the international criminal jurisdiction in the context of contemporary international law, doubly characterized by the extention and fragmentation. On the first topic, we discussed the ambiguity of the concept of jurisdiction, for shortly after address the main issues of international criminal jurisdiction - conceptual, institutional and historical development - to finally face the extension and fragmentation problems in this context. As an interim conclusion, we indicate the need for the international criminal cooperation is increasingly implemented.

Keywords: International Criminal Jurisdiction. Extension. Fragmentation. International Cooperation in Criminal Matters

\section{Considerações iniciais sobre o CONCEITO de JURISDiçÃo no DiReITO INTERNACIONAL}

** Professor Adjunto de Direito Internacional da Universidade Federal de Rondônia Mestre (UFSC) e Doutor (UERJ) em Direito Membro do Grupo de Pesquisas em Teoria Política Contemporânea
São de experiência universal estas cousas simples e profundas: $1^{\circ}$ - Os homens dissentem mais em virtude da equivocidade da linguagem que usem, do que pelas concepções que tenham das realidades em si. $2^{\circ}-\mathrm{O}$ conhecimento exato dos fenômenos sociais fará mais pela ordem jurídica e pela paz, do que o temor das forças motorizadas. $3^{\circ}$ - Quando o povo ignora 
os grandes princípios do Estado, a liberdade que ainda tenha é precária, ou já em ruínas. ${ }^{1}$

Essas lições de A. Sampaio Dória, proferidas no ano de 1946, não perderam nada de seus viços, pelo que se as toma como norte para a dilucidação do tema que será discutido neste trabalho, a jurisdição (penal) internacional.

Com efeito, a Ciência Jurídica Contemporânea reconhece como um traço constitutivo de sua epistemologia dois fatos importantes"2: a) o direito "é" linguagem, e onde esta vige não se busca a "essência" das coisas, mas o "uso" social das palavras. Em outros termos, desde a "linguistic turn" sabe-se que a vida "é" linguagem, na qual não existem "coisas", mas fatos e usos linguísticos por meio dos quais a comunidade de viventes busca atribuir significados e diretrizes para o seu agir; b) sendo o "uso" linguístico o referencial que se toma para a compreensão e a fixação de normas para o agir humano (a essência é uma consequência do uso linguístico, e não o seu suposto ${ }^{3}$ ), o traço mais próprio da linguagem humana é, em nível semântico, a ambiguidade, e que se levado a seu extremo pode desaguar na inexpressividade, dita anfibologia. Se, naquela, a comunidade de falantes experencia o fato de que uma determinada palavra pode identificar duas ou mais realidades distintas, esta se caracteriza como uma impossibilidade de comunicação e ou predicação ${ }^{4}$.

Assim, a primeira tarefa que cabe à Ciência do Direito é enfrentar a ambiguidade constitutiva de sua própria linguagem (sendo por isso caracterizada como uma metalinguagem), para, a partir disso, construir, racional e objetivamente, o significado jurídico-normativo dos conceitos, tornando possível a correta aplicação das

1 DÓRIA, A. Sampaio. Curso de Direito Constitucional (Os Direitos do Homem), t. 1, 2 ed., São Paulo: Cia Editora Nacional, 1946, Prefácio.

2 FERRAZ JR, Tércio Sampaio. Introdução ao estudo direito: técnica decisão dominação, 3 ed., São Paulo: Atlas, 2001, pp. 34-39.

3 Em outros termos, é o uso de tópicos axiológicos que atribui a uma determinada realidade o status de essência, e não o contrário. "1.1 Die Welt ist die Gesamtheit der Tatsachen, nicht der Dinge [...] 3.11 Wir benützen das sinnlich wahrnehmbare Zeichen (Laut - oder Schriftzeichen etc.) des Satzes als Projektion der möglichen Sachlage. Die Projektionsmethode ist das Denken des Satz-Sinnes". WITTGENSTEIN, Ludwig. Tractatus logico-philosophicus, Londres: Kegan Paul, Trench, Trubner \& Co, 1922, pp. 93/99.

4 AGAMBEN, Giorgio. Nota introdutória sobre o conceito de democracia, trad. Marcus Vinícius Xavier de Oliveira, in DANNER, Fernando, DANNER, Leno, KONZEN, Paulo Roberto. Democracia, política, representação: ensaios filosóficos, Porto Alegre, FI, 2014, pp. 11-15. normas jurídicas segundo seus próprios fundamentos. Com isto quer afirmar-se que, embora a linguagem do direito padeça das mesmas características semânticas da linguagem ordinária, ao discurso juridicamente significante, é possível e necessário perseguir e atribuir o seu telos jurídico-institucional e, com isso, evitar-se a anfibologia (o que, em último caso, levaria ao non liquet), pois à função interpretativa não é dissociada da função aplicativa, que nada mais é do que reconhecer, no momento mesmo de imputar as consequências jurídicas a um comportamento, humano ou institucional, que o "[...] ordenamento jurídico estabelece a realidade de fins, a preservação de valores e a manutenção ou a busca de determinados bens essenciais à realização daqueles fins e à preservação desses valores" 5 .

Esses fundamentos epistemológicos são tão ou mais válidos para o Direito Internacional quanto para o $\mathrm{Di}$ reito Nacional, na medida em que naquele, mais do que neste, a eficácia e a concretização de suas normas está condicionada, ora mais ora menos, aos interesses, historicamente, situados de seus principais atores, os Esta$\operatorname{dos}^{6}$. Conforme Pastor Ridruejo ${ }^{7}$,

comparado com os Direitos internos dos Estados, o Direito Internacional Público se nos apresenta como uma disciplina especialmente problemática, caracterizada por umas denunciadas carências institucionais que causam incertezas e relativismos no plano normativo, graves insuficiências na prevenção e na sanção de [sua] violação e uma politização alargada - ainda que não absoluta - na solução de controvérsias, quando não na impossibilidade de sua resolução.

Por suposto, a própria organização da Sociedade Internacional é a principal condicionante desses "problemas" do Direito Internacional ${ }^{8}$, mas também, o fato de

5 ÁVILA, Humberto. Teorias dos princípios: da definição à aplicação dos princípios jurídicos, São Paulo: Malheiros, 2003, p. 26. 6 Nesse sentido: "Apesar do aumento da gama de atores e participantes no sistema jurídico internacional, os Estados permanecem, de longe, como as pessoas coletivas mais importantes e, apesar do aumento da globalização e de tudo o que isso implica, os Estados mantêm a sua atração como o principal foco da atividade social humana e, portanto, do Direito Internacional" SHAW, Malcolm. International law, $6^{\text {th }}$ ed., Cambridge: Cambridge University Press, 2008, p. 197 (livre tradução).

7 PASTOR RIDRUEJO, José Antonio. Curso de derecho internacional público y organizaciones internacionales, $18 \mathrm{ed}$., Madri: Tecnos, 2014, p. 23 (livre tradução).

8 Para ficarmos na mais óbvia, a Sociedade Internacional é organizada horizontalmente ("tertio supra partes non datur"), enquanto que as sociedades nacionais são, por definição, verticais, na medida em que o Estado concentrada os poderes políticos fundamentais em sua própria estrutura institucional. Nesse sentido, BOBBIO, Norberto, 
a sua estrutura fundamental encontrar-se em um largo processo de transformação na qual ainda se encontra os traços caracterizadores do modelo westfaliano uma estrutura justaposta de Estados independentes que se coordenam entre si - , e o do modelo inaugurado pela Carta das Nações Unidas, dito Sistema da Carta?, que tende a conformar-se em uma estrutura de cooperação, vale dizer, em que a institucionalização normativa e orgânica da Sociedade Internacional tende(ria) a se sobrepor ao puro interesse dos Estados ${ }^{10}$ e, quiçá, conformar-se numa Comunidade Internacional constitucionalmente organizada ${ }^{11}$.

De qualquer modo, seja qual tenha sido, tenha ou venha a ter a estrutura da Sociedade Internacional, é certo que a jurisdição se constitui em um dos conceitos fundamentais do Direito Internacional, na medida em que através dele se identificam pelo menos três de seus institutos essenciais, a saber: 1) o conjunto de competências político-jurídicas nele contidos e atribuídos a um determinado órgão, 2) a soberania do Estado e 3) a competência jurisdicional atribuída pelo Direito Internacional aos diversos sistemas e regimes de soluções de controvérsias internacionais.

Que jurisdição abarque pelo menos três desses institutos fundamentais do Direito Internacional constitui-se em prova de que, nesse contexto, a Ciência do Direito Internacional se depara e opera com e na ambiguidade, sendo, pois, sua função, dilucidar os sentidos e aclarar os significados deste "[...] protean concepp 2 "12.

POLITO, Pietro (Org.). O terceiro ausente: ensaios e discursos sobre a guerra e a paz, trd. Daniela Versiani, São Paulo: Manole, 2009, pp. 287-290.

9 "La Charte des Nations Unies, en second lieu, qui a substitué au "modèle de Wetphalie", caractérisé par la force comme principale source de légitimité, le "modèle de la Charte" (ou "droit des Nations Unies") qui refuse toute légitimité au recours à la force". WEIL, Prosper. Le droit international en quête de son identité, Cours général de droit international public, RCAD vol. 237/1992, pp. 09370 (p. 28).

10 Nesse sentido, PASTOR RIDRUEJO, Curso de derecho internacional público..., pp. 48-49.

11 O que pressupõe, entre outros requisitos, a necessidade de que as jurisdições internacionais possam ser exercidas para além dos senões impostos pelos Estados. Conforme Thomas Kleinen: "Zentrale Elemente dieser dogmatischen Dimension der Konstitutionalisierungsthese sind die Hierarchisierung völkerrechtlicher Normen, die Herausbildung einer objektiven universellen Ordnung zun Schutz von Gemeinschaftsgütern und die Rechtsbindung der Ausübung von Hoheitsgewalt jenseits des Staates" KLEINEN, Thomas. Konstitutionalisierung im Völkerrecht: einer idealistichen Völkerrechtslehre, Heildeberg: Springer, 2012, p. 315.

12 BERMAN, Sir Franklin. Jurisdiction: the State, in CAPPSS,
No que concerne ao primeiro sentido, que se atribui ao conceito de jurisdição, o vocábulo identifica os fundamentos, contornos e limites para o exercício de uma competência jurídico-política. Para Patrick Capps, Malcolm Evans e Stratos Konstadinidis, a "Jurisdição' é uma forma de poder jurídico ou competência"13. Assim, a existência de uma jurisdição é precedida por uma decisão política fundamental pela qual se cria e se estabelecem as formas, modos e limites para o seu exercício, mas, principalmente, a sua atribuição para um órgão. Em outras palavras, a decisão política precede à atribuição jurídica da jurisdição porque, em última instância, é essa decisão que cria e confere legitimidade para o seu exercício. Com efeito, é competente — detém jurisdição — não quem assim o deseja, mas o órgão a quem a norma jurídica atribua o poder jurídico para agir.

Para compreender essa asserção, é preciso, mesmo que sinteticamente, aclarar que o vocábulo jurisdição é um conceito jurídico que abrange três espécies de competências político-jurídicas distintas, que podem, ou não, ser atribuídas a um mesmo órgão ${ }^{14}$ :

1)Legislativa (prescriptive jurisdiction), que é conjunto de competências político-jurídicas pertinente à capacidade legiferante, isto é, ao poder de criação de normas jurídicas;

2)Executiva (executive jurisdiction ou enforcement jurisdiction), que identifica o conjunto de competências político-jurídicas de autogoverno e legitimidade para perseguir a imputação das sanções jurídicas; e

3)Judiciária (adjudicative jurisdiction), que identifica o conjunto de competências político-jurídicas atribuídas aos órgãos de soluções de controvérsias para solver uma determinada lide.

Assim, e.g., quando se afirma que o Conselho de Segurança das Nações Unidas (doravante CSONU) é o órgão internacional que detém jurisdição internacional

Patrick, EVANS, Malcolm, KONSTADINIDIS, Stratos. Asserting jurisdiction: international ans european legal approaches, Portland: Hart Publishing, 2003, p. 3.

13 CAPPS, EVANS, KONSTADINIDIS, Asserting jurisdiction..., p. xix.

14 CAPPS, EVANS, KOSTANDINIDIS, Asserting jurisdiction..., xxi-xxiv; JANKOV, Fernanda F. F. Direito Internacional penal: mecanismos de implementação do Tribunal Penal Internacional, São Paulo: Saraiva, 2009, pp. 66-83; AKERURST, Michael, MALANCZUK, Peter (org.). Akehurt's modern introduction to internacional law, 17 ed., New York: Routledge, 1997, pp. 109-110. SHAW, International law, pp. 645-650. 
para manter a segurança e a paz internacionais (enforcement jurisdiction) (artigo 24, 1 da Carta das Nações Unidas, doravante CONU), devendo os Estados Membros das Nações Unidas acatar e executar as Resoluções desse Órgão (presciptive jurisdiction) no cumprimento de seu mandato internacional (artigo 25 da CONU) ${ }^{15}$, tal não se deve porque, assim, o querem os Estado Membros do CSONU, mas porque a atribuição dessa jurisdição foi precedida por um processo de deliberação política - a aprovação da CONU — em que os Estados acordaram em atribuir a esse órgão referida competência. De semelhante forma, quando se afirma que o Tribunal Penal Internacional (doravante TPI) detém competência ratione materiae para exercer a persecução penal e julgar (enforcement jurisdiction e adjucative jurisdiction) os autores dos crimes internacionais previstos no artigo 5, 1, a, b, c e d c/c artigos 6, 7 e 8 de seu Estatuto (nomeadamente, os crimes de agressão, genocídio, contra a humanidade e de guerra), mas não, v.g., o terrorismo internacional ou o tráfico internacional de estupefacientes ${ }^{16}$ e que, ademais, a competência ratione materiae para a persecução do crime de agressão está submetida a uma cláusula suspensiva (artigo 5, 2 do Estatuto do Tribunal Penal Internacional (doravante ETPI), isto se deve, em outros termos, ao fato de que, no curso do processo deliberativo que antecedeu à sua criação, os Estados envolvidos escolheram submeter à jurisdição do TPI determinados crimes (sem qualquer dúvida, os mais graves, e por isso mesmo denominados de core crimes), e outros não, bem como decidiram, em razão das enormes controvérsias

15 Trata-se, como sabido, das únicas Resoluções de Organização Internacional com eficácia cogente. AKEHURST, Akehurt's moderns introduction..., pp. 52-53.

16 A referência a estes dois crimes internacionais não é aleatória. Com efeito, a convocação da Conferência de Roma foi precedida, em 1989, pela discussão havida na Assembleia Geral da ONU (doravante ASONU) sobre o tráfico internacional de drogas, na qual a delegação de Trinidad e Tobago sugeriu a criação de um tribunal penal internacional com competência para a persecução desse crime. Tendo referida sugestão sido acatada pela AGONU, esta solicitou à Comissão de Direito Internacional (doravante CDI) que elaborasse o projeto de referido órgão. O resto, como se sabe, desaguou na criação do TPI, no qual nem se cogitou, no anteprojeto ou mesmo na conferência diplomática, em submeter este crime à jurisdição da corte. Nesse sentido, JAPIASSÚ, Carlos Eduardo Adriano. O Tribunal Penal Internacional: a internacionalização do Direito Penal, Rio de Janeiro: Lumen Juris, 2004, pp. 81 e ss. Já que no diz respeito ao crime de terrorismo, Antonio Casse afirma que no curso da Conferência de Roma se chegou a cogitar de submeter o terrorismo internacional à jurisdição do TPI mas, ante a falta de consenso sobre a própria tipificação do crime, referido projeto foi rechaçado. CASSESSE, Antonio. Lineamenti di diritto Internazionale penale I: diritto sustanziale, Bolgna: Il Molino, 2005, pp. 167-168. políticas pertinentes ao crime de agressão, mormente, por seu estreito liame com a competência do CSONU, aguardar que novas condições políticas se manifestassem para a tipificação de dito crime ${ }^{17}$.

Já em sua segunda acepção, o termo jurisdição identifica no Direito Internacional o conjunto de poderes político-jurídicos por ele assegurado para que os Estados, no exercício de sua independência, possam se autogovernar, interna e externamente. Em outros termos, jurisdição é sinônimo de soberania. E aqui se encontra, talvez, uma das maiores polêmicas política, jurídica e doutrinária no âmbito da história das ideias. Conforme afirmado alhures,

\begin{abstract}
Não parece existir um tema mais polêmico no plano das relações entre Direito Nacional e Direito Internacional do que o relativo à soberania, polêmica que opõe em polos distintos soberanistas e internacionalistas, oposição, ademais, que parece excluir uma via conciliatória, bastando lembrar, para fins de pontuação, a oposição entre monistas e dualistas no que diz respeito às relações entre Direito Internacional e direito interno.
\end{abstract}

Convém perceber, entretanto, que o termo polêmica (do gr. Polemikós ( $\pi 0 \lambda \varepsilon \mu u x o ́ s)$ ), tal como aqui empregado, se reporta em seu étimo a Pólemos

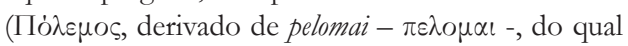
se originaram, por exemplo, to bustle, alvoroço, controvérsia etc) - que originalmente indicava ao daimon da guerra e da discórdia, e que por derivação metonímica, passou a nomear o próprio fato da discórdia, da guerra.

Faz-se essa digressão linguística para pôr em questão o próprio fato de sua origem, e que somente pode ser encontrada no âmbito da discórdia discursiva entre soberanistas e internacionalistas $[\ldots]^{18}$.

Para ficar no contexto do Direito Penal Internacional, essa polêmica se manifesta de forma muito insti-

17 O crime de agressão, desde a vigência do ETPI em 2002, estava submetido à cláusula suspensiva de vigência contida no artigo $5^{\circ}, 2$ do ETPI, que permitia o exercício jurisdicional do TPI sobre esse crime somente após a tipificação de seus elementos, o que foi feito, em parte, por ocasião da Conferência de Revisão do ETPI ocorrida em Kampala, Uganda, entre 31 de março e 11 de junho de 2010, restando, no entanto, a sua confirmação pela Assembleia dos Estados Partes do TPI a ocorrer em 2017. Consultar, nesse sentido, o Regulamento do TPI sobre os elementos dos crimes já revisado, disponível em http://www.icc-cpi.int/NR/rdonlyres/A851490E6514-4E91-BD45-AD9A216CF47E/283786/ElementsOfCrimesSPAWeb.pdf, acessado em 20/08/2011, às 14:31:00.

18 DE OLIVEIRA, Marcus Vinícius Xavier de Oliveira. Direito penal internacional, estado constitucional e o problema da mitigação da soberania na persecução dos crimes internacionais próprios, in DE OLIVEIRA, Marcus Vinícius Xavier. Temas escolhidos sobre a internacionalização do direito penal, Porto Alegre: FI, 2015, pp. 19-20. 
gante nas duas narrativas abaixo reproduzidas:

[...] Antonio Cassesse narra um diálogo por ele travado com um parlamentar de um Estado europeu logo após a criação do Tribunal Penal Internacional para a Ex-Iugoslávia - do qual ele foi o primeiro presidente - [...]. Disse o parlamentar a Antonio Cassesse: "As Comunidades Europeias estão expropriando nosso poder legislativo! E agora, vocês vêm, com esse Tribunal Internacional, retirar-nos o último bastião de nossa soberania: o poder de punir. Se as coisas continuarem assim, o Estado soberano acabará por se dissolver."

Mas o mesmo se passa na seara dos penalinternacionalistas, conforme, jocosamente, expressa Robert Cryer: "Quando a soberania aparece na área de estudo do Direito Internacional Penal, comumente vem vestida com chapéu e capa. Um cheiro de enxofre permeia o ar. Geralmente os estudiosos do Direito Penal Internacional vêm a soberania como inimiga. Ela é vista como irmã da realpolitik, frustrando a justiça penal internacional em cada rodada." 19

Nesse ponto tem-se, entretanto, e reduzindo-se a questão àquela primeira aproximação linguística, um manifesto mal-entendido, senão, má-fé, o que é válido para muitos casos, com enormes efeitos político-jurídicos no contexto do Direito Internacional. Um mal-entendido porque soberania é somente o conceito empregado pelas diversas disciplinas que se deparam com o problema político-jurídico da independência dos Estados vis-à-vis, mas que não se reporta nunca ao do Direito Internacional ${ }^{20}$. Má-fé porque, no contexto do Direito Internacional, soberania pode significar muitas coisas, mas jamais um poder acima do Direito Internacional e dos interesses dos demais Estados ${ }^{21}$.

Para solver qualquer mal-entendido - e espancar a má-fé - é preciso frisar que aquilo que em outras disciplinas se denomina soberania, no Direito Internacional é designado por jurisdição, isto é o conjunto de competências internacionalmente por ele asseguradas para que os Estados possam exercer os poderes necessários para,

19 DE OLIVEIRA, Direito Penal Internacional, Estado Constitucional..., p. 44.

20 "Uma palavra que se repete frequentemente nos escritos dos seguidores de Vattel é "soberania", e é duvidoso que qualquer outra palavra tenha causado tanta confusão intelectual e conflito [lawlessness] internacional". AKERURST, Akehurt's modern introduction..., p. 17.

21 "[...] a palavras ainda carrega uma tonalidade emotiva de poder ilimitado, acima da lei, e isso deu uma imagem totalmente enganosa das relações internacionais. $\mathrm{O}$ fato de um governante poder fazer o que ele quer em seus próprios assuntos não significa que ele possa fazê-lo, em questões de direito ou de poder político, a outros Estados". AKEHURST, Akehurt's modern introduction..., p. 17. conforme Vaugham Lowe "[...] criar, aplicar e executar as regras de conduta aos indivíduos. Relaciona-se, essencialmente, à extensão do direito do Estado de regular a conduta e as consequências dos eventos" "22 (grifos nossos), ou conforme Celso D. de A. Mello "O Estado tem o direito de exercer sua jurisdição sobre todas as pessoas e coisas no seu território nacional. As restrições à jurisdição estatal são impostas pelo DI"23 (grifos nossos). Com efeito, o artigo 2, 7 da CONU assegura que nenhum Estado ou organismo internacional poderá intervir “[...] em assuntos que dependam essencialmente da jurisdição de qualquer Estado [...]”, com o qual se conforma a moldura da chamada soberania interna a partir do princípio da não intervenção em assuntos de jurisdição interna. O o artigo 2, 1 assegura o princípio da igualdade de todos os Estados, com o qual se fixa os limites da soberania externa. Em outros termos, as competências para legislar, governar e julgar que os Estados detêm enquanto entidades internacionais independentes são asseguradas pelo Direito Internacional, sendo, além disso, mais do que induvidoso, que a soberania nunca foi concebida, internacionalmente, contra o Direito Internacional ${ }^{24}$, pois é, a partir dele, e não contra ele, que eles logram exercer plenamente suas jurisdições.

Por fim, o terceiro significado que se pode atribuir ao

22 Citado por JANKOV, Direito Internacional Penal..., p. 69. 23 MELLO, Celso D. de Albuquerque. Curso de Direito Internacional Público, t. I, 11 ed., Rio de Janeiro: Renovar, 2002, p. 428. 24 Esta é a concepção que se pode recolher entre os clássicos do Direito Internacional moderno: BODINO, Juan. Los seis libros de la Republica, t. I, trd. Gaspar de A. Isunza, Madri: Centro de Estudios Constitucionales, 1992, pp. 267 ess; GROTIUS, Hugo. O direito da guerra e da paz, vol. I, trd. Ciro Mioranza, Ijuí: Editora Unijui, 2044, pp. 175 e ss; DE VATTEL, Emer. O direito das gentes, trd. Vicente Marotta Rangel, Brasília: IPRI/Editora da UNB, 2004, pp. 1 e ss. Markus Kotzur chama à atenção para o fato de que a tríade caracterizadora da soberania na obra de Vattel ainda hoje orienta a compreensão da CIJ em sua jurisprudência: “[...] E. de Vattel tencionou fazer uma interpretação ampla da soberania estatal e estabeleceu uma diferenciação com base nas seguintes características: autogoverno, independência de outros Estados e vinculação direta ao Direito Internacional. A tríade de de Vattel marcou, e marca ainda hoje, a doutrina internacional sobre a soberania, a atuação dos Estados e a jurisprudência da Corte Permanente de Justiça Internacional, primeiro, e logo depois da Corte Internacional de Justiça. Consequentemente, um Estado é soberano quando não está submetido a nenhuma autoridade que não seja o Direito Internacional, quando pode adotar decisões obrigatórias últimas sobre os seus súditos em seu território (soberania interna) e quando é independente externamente, longe de todo influxo proveniente de outros Estados". KOTZUR, Markus. A Soberania Hoje. Palavras-Chave para um Diálogo Europeu Latino-Americano Sobre um Atributo do Estado Constitucional Moderno, trd. Marcus V. X. de Oliveira e Gabriel G. de Godói, Revista Quaestio Iuris, Rio de Janeiro, 2012, pp. 1-19. 
conceito de jurisdição no Direito Internacional decorre do fato de que determinados organismos internacionais detêm competência adjudicativa para a solução de controvérsias internacionais, abarcando uma pluralidade de sujeitos processuais bastante variados, isto é, desde os Estados e Organizações Internacionais, passando pela pessoa humana e chegando às empresas (o ICSID talvez seja o caso mais interessante nesse último caso). Em outros termos, jurisdição, tal como empregada nesse contexto, teria a mesma conotação atribuída no Direito Nacional para identificar os órgãos do poder judiciário.

Contudo, é interessante perceber que a constituição de um órgão com competência adjudicativa é precedida tanto pelo exercício coletivo de competência legislativa (de titularidade dos Estados envolvidos através de suas capacidades para celebrar tratados internacionais - jus tractuum), como do asseguramento de competência de autogoverno, v.g., mediante a atribuição de personalidade jurídico-internacional, dotação orçamentária, regime de tomada de decisões coletivas, delimitação de competência ratione materiae etc. Em outros termos, os órgãos adjudicativos internacionais estão inseridos, com relativa autonomia, em, ou constituem-se elas, de per se, em organizações internacionais, sendo o traço mais característico desse fato não a perda, mas a mitigação da soberania estatal, pois, se antes da constituição de referidos órgãos era assegurado aos Estados jurisdição exclusiva sobre a matéria, com a criação de organismo adjudicante para solver controvérsias, os Estados se submetem, facultativa ou obrigatoriamente, à sua jurisdição internacional (pacta sunt servanda), devendo cumprir suas decisões de boa-fé (bona fide) ${ }^{25}$.

Em conclusão parcial, é importante frisar a circunstância de que, contemporaneamente, o Direito Internacional tem experienciado o fenômeno de sua extensão normativa, isto é, uma contínua e ininterrupta regulação internacional de matérias que antes se submetiam à exclusiva jurisdição estatal, fenômeno este que tem causado não poucas perplexidades teóricas no contexto da disciplina. Com efeito, conforme Michael Akehurst,

hoje o Direito Internacional cobre vastas e complexas áreas de interesses transnacionais, incluindo tópicos tradicionais, como a posição, sucessão e responsabilidade dos Estados, paz

25 KOTZER, A soberania hoje..., passin. No tocante às organizações internacionais, KLABBERS, Jan. An introduction to international institutional Law, Cambridge: Cambridge University Press, 2002, pp. 1-16 e pp. 253-277. e segurança, o direito da guerra, o direito dos tratados, o direito do mar, o Direito Internacional dos cursos d'água e das relações diplomáticas, bem como novos tópicos, tais como as organizações internacionais, economia e desenvolvimento, energia nuclear, direito aéreo e outras atividades espaciais, o uso dos recursos em alto-mar, o meioambiente, comunicações e finalmente, mas não menos importante, a proteção internacional dos direitos humanos. Este desenvolvimento resultou em um incremento da especialização acadêmica $[\ldots] .{ }^{26}$

O campo específico deste artigo, a jurisdição internacional em matéria penal, envolve não poucas perplexidades frente ao Direito Internacional tradicional, seja porque toca num tema central de sua estrutura - a jurisdição para a persecução de crimes, tradicionalmente atribuídas aos Estados —, seja no que toca à complexa tessitura institucional e princiológica de relações entre Estados ou entre estes e organizações internacionais, seja, por fim, na afirmação de seu princípio fundamental, o da responsabilidade penal direta do indivíduo perante o Direito Internacional, tópicos estes que serão enfrentados a seguir.

\section{BREVE PERCURSO SOBRE O DESENVOLVIMENTO DA JURISDIÇÃO PENAL INTERNACIONAL}

Para compreender o percurso histórico da jurisdição penal internacional, é preciso, antes de qualquer coisa, compreender o significado da expressão crime internacional, porque é a partir desse conceito e das articulações entre jurisdição nacional e jurisdição internacional em matéria penal, que se pode, concretamente, aferir o seu desenvolvimento.

Denomina-se crime internacional qualquer comportamento humano a que uma norma internacional, convencional ou consuetudinária ${ }^{27}$, atribua, como uma consequência de sua realização, uma sanção penal, sendo que a persecução penal poderá ser exercida pelos próprios Estados, de conformidade com os seus orde-

26 AKEHURST, Modern introduction..., p. 7 (livre tradução). 27 "Os aspectos penais do Direito Internacional derivam das "convenções", "costumes" e "princípios gerais do direito", todos os quais são uma das fontes dessa disciplina jurídica tal como enunciado no artigo 38 do Estatuto da Corte Internacional de Justiça". BASSIOUNI, M. Cherif. Introduction to international criminal law, 2th edition, Leiden: Martinus Nijhoff Publishers, 2013, p. 9 (livre tradução). 
namento jurídicos, seja pelos tribunais penais internacionais. Três grandes problemas exsurgem dessa confluência entre Direito Penal e Direito Internacional.

A primeira alude não ao fato de que o Estado legisle sobre a matéria, mas que os Estados, no exercício de suas jurisdições internacionais, o façam. Em relação a esse fato, tem-se o pressuposto bastante evidente de que o comportamento humano de relevância jurídico-penal-internacional ofende, cumulativa ou alternativamente, ou a interesses comuns ou a interesses intrínsecos da Comunidade Internacional.

O segundo ponto problemático, especificamente grave para o Direito Penal de matriz liberal-garantista, decorre do fato de se considerar os costumes como fontes jurídicas de fatos impuníveis, na medida em que para este paradigma político-criminal, a única fonte legítima seria a lei formal ${ }^{28}$, e no Direito Internacional, os Tratados Internacionais.

Por fim, o terceiro foco de problemas respeita à circunstância de que a pessoa humana, e não o Estado seja sujeito passivo de uma sanção internacional, mais especificamente de caráter penal que, sem qualquer dúvida, é a forma mais grave de restrição à liberdade humana. Em outros termos, que o Direito Penal Internacional imponha uma sanção de caráter individual (à pessoa humana), e não coletiva (ao Estado ${ }^{29}$.

Contudo, ao se analisar referidos problemas em seu devido contexto, verifica-se que:

a) A criação de normas jurídico-penais no âmbito da Sociedade Internacional não é nem fato novo nem extraordinário. Com efeito, o crime internacional par excellence ainda no âmbito do Direito Internacional westfaliano foi o de pirataria, podendo-se remontar a sua incriminação ao século XVI, tendo como fundamento

28 Para ficarmos em um de seus mais renomados teóricos "O primeiro destes elementos é o convencionalismo penal, tal como resulta do princípio da legalidade estrita, na determinação abstrata do que é punível. Este princípio exige duas condições: o caráter formal ou legal do critério de definição do desvio [...]. O desvio punível [...] É aquele formalmente indicado pela lei como pressuposto necessário para a aplicação de uma pena, segundo a clássica fórmula nullum poena et nullum criminen sine lege [...] A primeira condição equivale ao princípio da reserva legal em matéria penal e da consequente submissão do juiz à lei [...]. FERRAJOLI, Luigi. Direito e razão: teoria do garantismo penal, 2 ed., trd. Juarez Tavares et al., São Paulo: RT, 2006, pp. 38-39.

29 KELSEN, Hans. Will the Judgment in the Nuremberg Trial Constitute a Precedent in International Law?, International Law Quaterly, v. 1, n. 2, summer 1947, pp. 15-171. doutrinário tanto a concepção ciceroniana de que o pirata se constituía em hostis humanis generis, como na doutrina de inúmeros internacionalistas da época (Alberico Gentili, Balthasar de Ayala e Hugo Grotius), para quem ela decorria de uma norma consuetudinária do Direito Internacional Geral, pela qual todo Estado detinha o poder-dever de persecução penal ${ }^{30}$.

b) No que toca, doutro giro, a se considerar o costume internacional como fonte legítima para a incriminação internacional não resta qualquer dúvida de que, à luz do paradigma liberal-garantista, ocorre, sim, violação ao postulado nullum crimen sine lege scripta. Contudo, nem a Sociedade Internacional é um super Estado, nem o princípio rule of law se aplica, integralmente, na conformação de seu ordenamento jurídico. Os costumes internacionais ainda são fontes por excelência do Direito Internacional ${ }^{31}$ - ao lado dos Tratados Internacionais. Mormente, no que toca aos core crimes, a acusação de violação ao postulado do princípio da legalidade em Direito Penal foi, satisfatoriamente, colmatado com a aprovação do ETPI e do seu Regulamento dos Elementos dos Crimes $^{32}$.

c) Por fim, no que concerne ao princípio da responsabilidade direta do indivíduo perante o Direito Penal Internacional, uma clara dissonância em relação ao instituto da responsabilidade coletiva, é importante notar que ela se estabeleceu, com os Julgamentos de Nuremberg e Tóquio, como uma norma aceita pela Sociedade Internacional, mormente após a aprovação, pela

30 BASSIOUNI, M. Cherif. Universal jurisdiction for international crimes: historical perspectives and contemporary practice, Virginia Journal of International Law, n. 42, v. 81, fall 2001, pp. 13-14.

31 GUGGENHEIM, Paul. Contribution a l'historie des sources du Droit des Gens, RCADI, vol. 94 (1958-II), p. 36 : « [...] la coutume, au point de vue de la doctrine, est la source originair et la plus importante. C'est d'elle que la seconde des sources, la convention tira sa validité $[. .]$.

32 Nesse sentido, AMBOS, Kai. La parte general del derecho penal internacional: bases para una elaboración gomática, trd. Ezequiel Malarino, Berlin/Montvideo: Konrad-Adenauer Stiftung, 2005, pp. 35-37. Já M. Cherif Bassiouni defende, sem meias palavras, a legitimidade dos costumes internacionais, mormente porque, no Direito Penal Internacional, ele não é nem pode ser dissociado da prática nacional dos Estados no tocante à persecução dos crimes, como por ser o costume internacional uma fonte primária do Direito Internacional, muito embora ele ponha um acento excessivamente dissonante na opinio juris sobre o usus. "The binding character of customary international law is not only based on state practice, but also evidenced by states' intentions to be bound by certain practices, opinio juris". BASSIOUNI, M. Cherif. Crimes against humanity: historical evolution and contemporary application, Cambridge: Cambridge University Press, 2011, pp. xi/xxvii-xix. 
AGONU, da Resolução sobre os Princípios do Direito Internacional Reconhecidos pela Carta do Tribunal de Nuremberg, de 1950, segundo o qual, em seu artigo $1^{\circ}$ "Qualquer pessoa que cometer um ato que constitua um crime sob o Direito Internacional é [por ele] responsável e passível de ser julgado"33 , pelo que hoje não remanesce nenhuma dúvida quanto à sua legalidade e legitimidade ${ }^{34}$.

Se, portanto, crime internacional é todo fato impunível criado pela ação coletiva dos Estados, remanesce o problema de se definir o como do exercício das jurisdições penais de persecução e adjudicação, vale dizer, o modo pelo qual os Estados e/ou os organismos internacionais exercem a persecução penal dos autores dos crimes internacionais. Para responder a este problema é preciso considerar que o exercício dessas competências leva em conta dois critérios distintos. A primeira diz respeito à dintingo entre crimes internacionais próprios e crimes internacionais impróprios, também denominados de crimes internacionais transnacionais. A segunda se reporta à conformação internacional entre a persecução penal de competência nacional, dita indirect enforcement, e a persecução penal de competência internacional, dita direct enforcement, sendo que a prática contemporânea do Direito Penal Internacional criou uma terceira variante, os tribunais internacionais mistos.

Com relação àquela primeira distinção, denominam-se crimes internacionais próprios, ou também core crimes, international crimes stricto sensu, crimes against international law, jus cogens international crimes, dentre outros ${ }^{35}$, aos fatos impuníveis internacionais de maior gravidade no Direito Internacional, posto que ofendem os interesses, direitos e princípios fundamentais da Sociedade Internacional. Por isso são os crimes nucleares (core crimes) e, passados largos anos desde Nuremberg e Tóquio (os primeiros tribunais penais internacionais), foram definitivamente submetidos à jurisdição penal do TPI, muito embora vários desses crimes, também, sejam, internacionalmente, regulados por convenções internacionais específicas $^{36}$. Assim, o crime de agressão, os crimes con-

33 ONU. "Principles of International Law Recognized in the Charter of the Nürnberg Tribunal and in the Judgement of the Tribunal", Yearbook of the International Law Comission, 1950, vol. II, p. 97 (livre tradução).

34 AMBOS, La parte general..., pp. 34-35.

35 BASSIOUNI, Introduction to International Criminal Law..., p. 142.

36 V.g. Convenção para a Prevenção e Repressão do Crime de Genocídio, a Convenção contra a Tortura e outros Tratamentos ou tra a humanidade, o genocídio e os crimes de guerra são fatos impuníveis internacionais porque, à luz da atual conformação da Sociedade Internacional, é inadmissível que os seus autores fiquem impunes, mormente porque esta impunidade é, por definição, fática, e não jurídica. Fática porque, nada obstante ser mais do que claro o rechaço político e jurídico de tais práticas, bem como a tipificação da maior parte destes crimes pelos próprios Estados e pelo Direito Internacional, a persecução penal em nível interno ainda se condiciona, em muitos casos, à ineficiência deliberada, querida e ilícita de quem esteja exercendo o poder, de fato ou de direito ${ }^{37}$.

Já os crimes internacionais impróprios, também denominados de international crimes largo sensu ${ }^{38}$ ou crimes transnacionais ${ }^{39}$, são os fatos impuníveis internacionais que violam a determinados interesses da Comunidade Internacional, sejam eles pertinentes, v.g., à prevenção de um determinado comportamento de caráter econômico (tráfico internacional de drogas, corrupção, criminalidade organizada etc.) ou mesmo à violação de direitos humanos (tráfico internacional de pessoas, pornografia infantil etc) e que, por conveniência política, se ajustaram formas de prevenção geral e especial de dito comportamento mediante a cooperação penal internacional entre os Estados. São, sem qualquer sombra de dúvida, os mais numerosos, muitos deles de manifesta conotação econômica, pelo que, também, ocorreu a incriminação internacional da lavagem de capitais, forma de criminalidade financeira que atravessa, por assim dizer, todos os demais crimes transnacionais ${ }^{40}$.

A distinção entre crimes internacionais próprios e impróprios é fundamental para a compreensão do como do exercício da jurisdição penal internacional na medida em que, sinteticamente, a prática de crimes in-

Penas Cruéis, Desumanos ou Degradantes e a Convenção Internacional para a Proteção de Todas as Pessoas Contra os Desaparecimentos Forçados, sendo que estes dois últimos crimes internacionais são também punidos na forma de crimes contra a humanidade, ex vi do artigo $7^{\circ}$ do ETPI.

37 Por todos, AMBOS, Kai, KARAYAN, Monica. Impunidad y Derecho Penal Internacional, 2 ed., Buenos Aires: Ad Hoc, 1999, pp. 33-60.

38 BASSIOUNI, Introduction to International Criminal Law..., p. 142.

39 GIL-GIL, Alicia. Derecho Penal Internacional, Madri: Tecnos, 1999, pp. 35-36.

40 Sobre o tema, A internacionalização do direito penal: uma aproximação a partir do crime de lavagem de capitais, in DE OLIVEIRA, Marcus Vinícius Xavier. Temas escolhidos sobre a internacionalização do direito penal, Porto Alegre: FI, 2015, pp. 130-163. 
ternacionais próprios enseja a possibilidade de exercício de várias formas de jurisdição penal, seja pelos Estados - jurisdição penal concorrente entre competência territorial e jurisdição penal extraterritorial decorrente do princípio da justiça universal - e isso em razão da regra de conexão da incriminação internacional ${ }^{41}$, seja por Tribunais Penais Internacionais, em especial o TPI, que se orienta pelo princípio da complementariedade, nos termos dos artigos 1 e 17 do ETPI. ${ }^{42}$

Já os crimes internacionais impróprios ensejam, somente, a persecução penal de caráter nacional, territorial e/ou extraterritorial, inclusive na forma da jurisdição universal pelos demais Estados, em concorrência

41 Colha-se o seguinte trecho da decisão do Tribunal Constitucional espanhol nos autos do Sentença 237/2005: "El principio de subsidiariedad no aparece recogido en nuestro Derecho positivo, ni en la LOPJ ni en el Convenio sobre genocidio, que efectivamente no prohíbe la jurisdicción universal respecto de ese delito, existiendo de hecho diversos países que la han establecido en sus legislaciones. La jurisdicción universal «no se rige por el principio de subsidiariedad, sino por el de concurrencia, pues precisamente su finalidad es evitar la impunidad», aplicándose el principio de no necesidad de intervención cuando está actuando la jurisdicción territorial. Esto no faculta para exigir la acreditación plena de la inactividad de dicha jurisdicción territorial para admitir la querella, sino la aportación de indicios razonables de que los crímenes denunciados no han sido hasta la fecha perseguidos de modo efectivo, lo que se desprende en este caso de la documentación aportada. Por ello la estimación del recurso de casación en relación con la aplicación del principio de subsidiariedad debió determinar la admisión de la querella en los términos del Auto dictado por el Juzgado Central, y puesto que la subsidiariedad constituía la única fundamentación del Auto de la Sala de la Audiencia Nacional, que es considerada incorrecta por la mayoría, lo consecuente habría sido casar el Auto recurrido."

42 É importante frisar: o princípio da complementariedade se aplica ao TPI. Com relação ao Tribunal Penal Internacional para a Ex-Iugoslávia (doravante ICTY) e ao Tribunal Penal Internacional de Ruanda (doravante ICTR), segundo William Schabas é regido pelo “[...] regime [...] conhecido por primazia, segundo o qual os tribunais ad hoc podem assumir a jurisdição de direito, sem a necessidade de demonstrar a falha ou insuficiências do sistema nacional [...]". SCHABAS, William A. An introduction to the International Criminal Court, 4 ed., Cambridge: Cambridge University Press, 2011, pp. 190-191. Com efeito, mencionados tribunais, em seus respectivos Estatutos, estabelecem o princípio da primazia de suas jurisdições sobre as jurisdições dos Estados nacionais, conforme, respectivamente, os artigos $1^{\circ}$ e 9, 1 do EICTY, de 25 de maio de 1993 e os artigos $1^{\circ}$ e 8, 1 do ECTIR, de 08 de novembro de 1994. No mesmo sentido BAZELAIRE, Jean-Paul, CRETIN, Thierry. A justiça penal internacional: sua evolução, seu futuro de Nuremberg a Haia, trd. Luciana P. Venâncio, Bauru: Manole, 2004, pp. 9597. Sobre os referidos Tribunais ad hoc consultar as excelentes monografias de HAGAN, John. Justice in the Balcans: prosecuting war crimes in the Hague Tribunal, Chicago: Chicago University Press, 2003 e CRUVELLIER, Thierrry. Court of remorse: inside the International Criminal Court for Rwanda, trd. Chari Voss, Madison: University of Wisconsin Press, 2006. ou não. Em outros termos, nenhum crime transnacional está submetido à jurisdição de um Tribunal Penal Internacional.

Nisso se caracteriza, portanto, a conformação da jurisdição penal internacional em matéria penal a partir dos conceitos de direct enforcement e indirect enforcement.

O regime da direct enforcement legitima que a persecução penal dos autores dos crimes mais graves no Direito Internacional sejam indiciados, julgados e, eventualmente, condenados pelos tribunais internacionais. Historicamente são três os princípios de fixação da jurisdição penal internacional direta dos tribunais internacionais ${ }^{43}$ :

A) Da exclusividade: orientou a competência dos Tribunais Penais de Nuremberg e Tóquio, dado que os Estatutos dessas cortes estabeleceram a jurisdição direta sobre os sujeitos passivos do processo de incriminação com total exclusão da jurisdição dos tribunais nacionais ${ }^{44}$.

B) Da primazia: foi o princípio adotado pelo CSONU quando da criação dos Tribunais Penais $A d H o c$ da Ex-Iugoslávia e de Ruanda, em razão da qual, havendo conflito jurisdicional entre ditos tribunais e competência ratio loci ou ratio personae dos tribunais nacionais, prevalece a dos tribunais internacionais. No entanto, por juízo discricionário do tribunal internacional, é possível que o caso seja transferido para a competência do tribunal nacional competente. ${ }^{45}$

C) Da complementariedade: é o princípio organizativo do ETPI, pelo qual este tribunal somente poderá exercer sua jurisdição caso se comprove que, ou o Estado competente não pode ou não quer exercer a persecução penal, ou, caso a tenha exercido, tenha ocorrido julgamento simulado. ${ }^{46}$

A diversidade de princípios que fixam a competência adjudicativa desses diversos tribunais penais internacionais decorre essencialmente do contexto histórico em que eles foram criados. Se Nuremberg e Tóquio foram, apesar dos avanços significativos que representaram para a criação e consolidação da jurisdição penal inter-

43 BASSIOUNI, Introduction to international criminal law..., pp. 28 et seq.

44 WERLE, Gerhardt. Principles of International Criminal Law, $2^{\text {th }}$ edition, Hague: T M C Asser Publishers, 2009, p. 81.

45 WERLE, Principles of International Criminal Law..., p. 82. 46 SCHABAS, An introduction to the International Criminal Court..., p. 190 et seq; WERLE, Principles of International Criminal Law..., pp. 83 et seq. 
nacional, verdadeiros julgamento de vencedores sobre os vencidos ${ }^{47}$, os Tribunais $A d$ Hoc tiveram origem em resoluções do CSONU, sendo certo, portanto, que somente o TPI passou pelo crivo do difícil e custoso processo de deliberação político-internacional para a sua criação sendo, nesse sentido, não a criação de um poder externo ou, no caso do CSONU, prevalecente aos Estados, mas da Sociedade Internacional ${ }^{48}$.

Já o regime indirect enforcement, aplicável aos crimes internacionais próprios e transnacionais, é aquele em que a persecução penal dos autores dos crimes internacionais é exercida pelos próprios Estados por meio das competências territorial e extraterritorial. Nesse caso, é condição necessária e inafastável para que referida persecução ocorra que os Estados tipifiquem, em seus respectivos ordenamentos jurídicos, os crimes internacionais, o que envolve, noutro passo, o surgimento da complexa tessitura decorrente da internacionalização do direito ${ }^{49}$. Como afirmado noutro lugar,

os diversos modos pelos quais o Direito Nacional e o Direito Internacional se intersectam nessa complexa tessitura normativa denominada de internacionalização do direito comporta, conforme Mireille Delmas-Marty, três modos básicos, sempre operados através de tratados internacionais, a saber:

a) unificação: trata-se da hipótese identificada por Jacob Dolinger sob a rubrica do direito

47 Hans Kelsen indicava, como condição de justiça internacional, a necessária reciprocidade internacional, ou seja, quem quer julgar deve dispor-se a ser julgado. KELSEN, Hans. A paz garantida pela responsabilização individual por violações do Direito Internacional, in A paz pelo direito, trad. Lenita A. do Nascimento, São Paulo: Martins Fontes, 2011, p. 106. Já M. Cherif Bassiouni é mais incisivo ao discutir a questão a partir do conflito entre o caráter erga omnes do Direito Penal Internacional e a realpolitik, quando afirma que "Os processos pós Segunda Guerra Mundial eram basicamente para os derrotados [...] Nenhum membro das forças aliadas jamais foi processado por um crime de guerra. Ninguém levantou a questão de crimes de guerra ou crimes contra a humanidade sobre o bombardeamento deliberado da cidade de Dresden, que não tinha nenhum valor militar, e que resultou na morte de 35.000 civis. Não se questionou muito sobre os bombardeamentos atômicos das cidades civis Hiroshima e Nagazaki, que resultaram em uma estimativa de 250.00 vítimas que morreram em decorrência do ataque [...]". BASSIOUNI, M. Cherif. The perenial conflict between international criminal justice and realpolitik, in Miller Lecture, Georgia State College of Law, 2006. Disponível em www.law.gsu. edu/Miller_Lecture/2006/MillerLecture-S06-BassiouniDraft.pdf, acessado em 30/10/2011.

48 Sobre a "luta" para a aprovação do ETPI no curso da Conferência Diplomática de Roma entre os dias 15 de junho a 17 de julho de 1998, consulte a narrativa de JAPIASSÚ, O Tribunal Penal Internacional..., pp. 112-116.

49 DELMAS-MARTY, Mireille.. Trois défis pour un droit mondial, Paris: Éditions du Seuil, 1998, p. 118 e ss. uniformizado (ou direito uniforme espontâneo), pelo qual os Estados ajustam um tratamento unificado de determinados institutos jurídicos que deverão ser regulados, em âmbito interno de acordo com o estabelecido pelo Direito Internacional.

b) uniformização: busca estabelecer um tratamento uniforme a determinados institutos jurídicos no bojo dos ordenamentos estatais, que deverão, conforme a sua cultura jurídica e os seus princípios fundamentais, dar eficácia interna às normas internacionais. Nesse sentido, é comum que os tratados internacionais, diversamente do que ocorre na unificação, regule a matéria através de princípios ou regras gerais que permitam aos Estados adequar as suas legislações ao regramento internacional.

c) harmonização: nessa hipótese, por fim, buscase, na melhor medida do possível, uma harmonia entre o que é assegurado internacionalmente e aquilo que é vivido em âmbito nacional diante do pluralismo político e cultural que viceja nas mais diversas nações. Trata-se, portanto, da constatação da impossibilidade de uniformização e pela busca de um compromisso que permita um grau mínimo de coesão acerca de determinada matéria, servindose o Direito Internacional, mais uma vez, de mandados de internalização das matérias mediante regras e princípios gerais. ${ }^{50}$

Essas última asserção insere o presente trabalho em dos dois temas mais complexos do Direito Internacional contemporâneo, expansão e fragmentação, e que serão enfrentados no próximo tópico.

Por fim, a prática contemporânea do Direito Penal Internacional, também, se tem utilizado do regime misto instituído pelos tribunais nacionais internacionaliza$\operatorname{dos}^{51}$, ou "mixed models of Internacional Criminal Justice"

Nesse regime híbrido, iniciado com a criação da Corte Especial para Serra Leoa, constituída pelo acordo forjado entre este Estado e o CSONU ${ }^{53}$, é conformado segundo os mesmos princípios dos Tribunais Internacionais $A d H o c$, vale dizer, o princípio da primazia

50 DE OLIVEIRA, Marcus Vinícius Xavier. A internacionalização do direito da execução penal: em que(quais) sentido(s)?, in DE OLIVEIRA, Marcus Vinícius Xavier. Temas escolhidos sobre a internacionalização do direito penal, Porto Alegre: Fi, 2014, pp. 274-306.

51 WERLE, Principles of Internacional Criminal Law.., p. 101-106.

52 BASSIOUNI, Introduction to International Criminal Law..., pp. 721-784.

53 "The Agreement was signed on 16 January 2002 and can be found in the appendiz of the Report of the Planning Mission on the Establishment of the Special Court for Sierra Leone Transmitted by the Secretary-General to the President of the Security Council by letter Dated 6 March 2002 of 8 March 2002”. WERLE, Principles of International Criminal Law..., pp. 102-103. 
sobre os demais órgãos jurisdicionais do Estado, detendo competência para julgar fatos que antecederam à criação da Corte. A composição do Tribunal é mista - juízes nacionais e estrangeiros, sendo estes indicados pelo Secretário Geral da ONU, tendo por competência a persecução penal dos autores dos core crimes praticados no curso da guerra civil ocorrida no país, sejam seus autores nacionais ou estrangeiros.

À Corte Especial de Serra Leoa se seguiram outros tribunais internacionais mistos - Kosovo, Bósnia e Herzegovina, Timor Leste, Camboja, Líbano - , sendo a maior deles constituídos mediante Acordo entre estes Estados e o $\mathrm{CSONU}^{54}$, não existindo, entretanto, uma unidade no que concerne à jurisdição ratione materiae, já que o direito aplicável por essas Cortes é tanto o Direito Penal Internacional como o próprio Direito Nacional dos Estados, do que exsurge uma pluralidade conteudística de normas penais irredutíveis a uma sistematização ${ }^{55}$.

\section{JURISDIÇÃO PENAL INTERNACIONAL: ENTRE EXTENSÃO E FRAGMENTAÇÃO}

A compreensão do fenômeno da jurisdição penal internacional está atrelada ao contínuo processo de alargamento normativo e institucional pelo qual tem passado o Direito Internacional contemporâneo, e que resta melhor compreendido a partir dos conceitos expansão e fragmentação.

Por expansão do Direito Internacional compreende-se a contínua ampliação da regulação internacional de matérias que, sob a perspectiva do Sistema Westfaliano, se encontravam sob a exclusiva jurisdição dos Estados, ou quando muito, eram reguladas internacionalmente por meio de tratados bilaterais.

Assim, desde o surgimento do Sistema da Carta, e mais ainda com o término da Guerra Fria e o fenômeno da globalização econômica, o Direito Internacional tem passado a regular um conjunto cada vez mais amplo de matérias que passam a influir e modificar, de forma decisiva, não somente a própria estrutura do sistema internacional, mediante, e.g., a constituição de inúme-

54 A exceção é a de Timor Leste, instituído pela Resolução 2000/11 da UNTAET, de 06 de março de 2000.

55 BASSIOUNI, Introduction to International Criminal Law..., pp. 721-784. ras organizações e regimes internacionais e o espocar de múltiplos tratados-normativos multilaterais, universais e/ou regionais, mas também, e principalmente, na forma como os próprios Estados, no exercício de suas jurisdições, tomam decisões políticas, seja para adequar os seus sistemas normativos nacionais a essas contínuas afluências de normas internacionais e, a partir delas, dirigir as suas políticas internacionais, seja para rechaça$-1 a s^{56}$.

Qual Janus, o Estado, no exercício de suas jurisdições, é dotado de dois "rostos", um que olha para aquilo que lhe externo - as relações internacionais —, e outro que olha para dentro - o governo livre e desimpedido de seu território e população, segundo o seu próprio ordenamento jurídico — em outras palavras, soberania interna e soberania externa. Se antes este dúplice olhar e governar se encontravam imunes, juridicamente falando, a intervenção internacional quase de forma absoluta, hoje não mais, podendo-se falar numa contínua mitigação da soberania, interpretável a partir do conceito de Estado Constitucional Cooperativo ${ }^{57}$. Sendo a soberania (rectius: a jurisdição estatal) assegurada e delimitada pelo Direito Internacional, ali onde este se expande, aquela tende a se retrair, sendo a sua contínua mitigação, mediante o surgimento e a ampliação de formas de atuação internacional cooperativa, nas quais os Estados compartilham entre si as jurisdições sobre determinadas matérias ${ }^{58}$, um dado da realidade que não pode ser afastado por quem deseja compreender a intersecção entre Direito Nacional e Direito Internacional ${ }^{59}$.

Por seu turno, entende-se por fragmentação do Direito Internacional, também denominada de "diferen-

56 LOCK, Grahame. Ringing the changes: mutations in the idea of political change, in KERSBERGEN, Kees van et all (Orgs.). Expansion and fragmentation: internationalization, political change and the transformation of the Nation State, Amsterdam: Amsterdam University Press, 1999, pp. 23-42.

57 KOTZUR, Markus. A soberania hoje: palavras-chave para um diálogo europeu-latino-americano sobre um atributo do Estado Constitucional moderno...; HÄBERLE, Peter. El Estado Constitucional, trad. Héctor Fix-Fierro, Cuidad de Mexico: UNAM, 2003; HÄBERLE, Peter, KOTZUR, Markus. De la soberanía al derecho constitucional común: palabras clave para un diálogo europeu-latinoamericano, trad. Héctor Fix-Fierro, Cuidad de Mexico: UNAM, 2003; HÄBERLE, Peter. O Estado Constitucional Cooperativo, trad. Marcos A. Maliska e Elisete Antoniuk, Rio de Janeiro: Renovar, 2007.

58 KOTZUR, A soberania hoje....

59 DE OLIVEIRA, Direito Penal Internacional, Estado constitucional e o problema da mitigação da soberania na persecução dos crimes internacionais próprios..., p. 60 e ss. 
ciação funcional" "60, o fenômeno normativo-estrutural decorrente de sua expansão, e que tem por uma de suas características mais proeminentes a quebra dos princípios sistemáticos da unidade e da coerência no âmbito desse ramo jurídico. Se no sistema westfaliano o Direito Internacional era, essencialmente, de caráter geral e consuetudinário, hoje, com o sistema da carta, ele se dispersa normativamente numa série de regramentos universais e regionais; em Direito Internacional Geral, ainda, majoritariamente, consuetudinário, e direitos internacionais especializados instituídos por tratados-normativos multilaterais, com regimes jurídicos e sistemas de solução de controvérsias próprios ${ }^{61}$, em face dos quais os usais critérios de solução de conflitos normativos aplicáveis no Direito Internacional — especialidade e cronológico - parecem não render efeitos concretos para a solução de muitos conflitos, ocorrendo, no mais das vezes, uma sobreposição de normas e sistemas de solução de controvérsias autônomos vis-à-vis, pondo em risco a própria ideia de sistema normativo no contexto do Direito Internacional ${ }^{62}$.

Conforme Marcelo D. Varella e Vitor E. T. de Oliveira $^{63}$,

[...] o fenômeno da diferenciação funcional ou fragmentação resume-se no aparecimento de normas, complexos de normas, instituições jurídicas ou esferas de práticas jurídicas igualmente especializadas e relativamente autônomas [...]" sendo que "[...] a produção destas normativas e instituições tende a ocorrer de forma não paralela com os conhecimentos e práticas gerais do Direito Internacional, gerando conflitos entre normas ou sistemas de normas, bem como a perda de uma perspectiva geral do direito, resultando também, indubitavelmente, em uma diminuição da almejada segurança jurídica, haja vista que não é mais possível prever a reação de instituições oficiais e planejar atuações de acordo com ela. A fragmentação

60 KOSKENNIEMI, Martti. Fragmentation of international law: difficulties arising from the diversification and the expansion of International Law - Report of the Study Group of the International Law Commission. INTERNATIONAL LAW COMMISSION, Fifty-eighth session, Geneva, 1 May-9 June and 3 July-11 August 2006, p. 11.

61 GOUVEIA, Jorge Bacelar. Manual de Direito Internacional público, Rio de Janeiro: Renovar, 2005, pp. 17-27.

62 Sobre o tema a partir da ciência do direito, CANARIS, ClausWilhelm. Pensamento sistemático e conceito de sistema na Ciência do Direito, 2 ed., trad. A. Menezes Cordeiro, Lisboa: Fundação Calouste Gulbenkian, 1996.

63 VARELLA, Marcelo D., de Oliveira, Vitor Eduardo Tavares. "Da unidade à fragmentação do Direito Internacional: o caso Mox Plant", Revista da Faculdade de Direito da UFMG, Belo Horizonte, n. 54, jan/jun 2009, pp. 119-140 (128-129). do Direito Internacional é fruto da expansão da atividade normativa e jurisdicional internacional em diversos novos campos, bem como a diversificação de seus objetos e técnicas.

Birgit Schlütter ${ }^{64}$, em seu estudo sobre o desenvolvimento do Direito Internacional consuetudinário a partir da jurisprudência da CIJ e dos ICTY e ICTR, compartilha a opinião de diversos autores do Direito Penal Internacional de que esse ramo está, profundamente, imbricado nesse contexto fragmentário, principalmente em razão de que as suas inúmeras especificidades tem-no afastado, cada vez mais, dos fundamentos ("roots") do Direito Internacional Geral, seja no que concerne à matéria regulada (v.g., o princípio da reponsabilidade penal direta do indivíduo segundo o Direito Internacional, já que, no regime do Direito Internacional westfaliano, a regra era a da responsabilidade coletiva, isto é, dos Estados), seja no que diz respeito a uma específica concepção das fontes normativas que o regulam, seja, por fim, pela existência de diversos regimes de implementação da persecução penal, e cita, como espeque dessa compreensão, as lições de Ruiz-Fabri, para quem

D'un point de vue systémique, l'impression qui en résulte est celle d'une concrétisation de la fameuse «fragmentation » du droit international. Certes, c'est en des termes limités puisqui'il ne s'agit pas de nier l'existence de la règle, simplement son accessibilité et son applicabilité. Mais, comme tout raisonnement fondé sur la spécifiité, il tend à séparer, l'argument trouvant toutefois sa limite dans l'objection qu'il faudrait démonter sa préexistence d'une quelconque unité du droit international. ${ }^{65}$

Portanto, é sobre esse pano de fundo do atual sistema internacional que se deve compreender o fenômeno da expansão da jurisdição penal internacional, bem como as exigências político-jurídicas decorrentes da expansão do Direito Internacional sobre essa matéria.

Com efeito, tanto a expansão como a fragmentação se apresentam como características constitutivas desse campo especial do Direito Internacional contemporâneo.

No que respeita à expansão, essa característica fica comprovada pelo fato de que entre os anos de 1815 e 1999 o sistema internacional produziu um conjunto de

64 SCHLÜTTER, Birgit. Developments in customary International Law: theory and the practice of the International Court of Justice and the International ad hoc Criminal Tribunals for Rwanda and Yugoslavia, Leiden: Martinus Nijhoff, 2010, p. 116.

65 Citado por SCHLÜTTER, Developments in customary International Law..., p. 116. 
27 categorias de crimes internacionais através da promulgação de 276 convenções internacionais ${ }^{66}$, instituindo formas bastante variadas para a persecução desses crimes, desde a atribuição de competência penal extraterritorial para os Estados, até a constituição de Tribunais Penais Internacionais, próprios ou de caráter misto.

M. Cherif Bassiouni ${ }^{67}$, buscando sistematizar essas diversas categorias de crimes internacionais a partir dos bens jurídicos tutelados (ratione materiae), forjou uma classificação quadripartida assim constituída ${ }^{68}$ :

\section{A) Proteção à paz e segurança internacionais:}

- Crime de Agressão.

B) Proteção a interesses humanos não associados a outros interesses internacionalmente protegidos

- Genocídio;

- Crimes contra a humanidade;

- Crimes de guerra;

- A posse, o uso, o armazenamento e o comércio ilegais de armas, incluídas as armas nucleares;

- Terrorismo nuclear;

- Apartheid;

- Escravidão, redução à condição análoga à escravi-

66 BASSIOUNI, M. Cherif. Universal jurisdiction for international crimes..., p. 13. É importante frisar que o recorte histórico fixado por Bassiouni neste trabalho foi o ano de 1999. Contudo, já no ano de 2000 foram aprovados diversos tratados internacionais sobre a matéria, a saber: a Convenção das Nações Unidas contra o Crime Organizado Transnacional (doravante, Convenção de Palermo), e seus dois Protocolos Adicionais, o primeiro Relativo ao Tráfico de Migrantes por via Terrestre, Marítima e Aérea e o segundo para a Prevenção, Repressão e Punição do Tráfico de Pessoas, em Especial Mulheres e Crianças; dois protocolos facultativos à Convenção sobre os Direitos das Crianças de 1989, o primeiro referente à Venda de Criança, à Prostituição Infantil e à Pornografia Infantil, e o segundo Relativo ao Envolvimento de Crianças em Conflitos Armados; e a Convenção das Nações Unidas contra a Corrupção. Já em 2005 foi aprovada a Convenção Internacional para a Repressão dos Atos de Terrorismo Nuclear, dentre outros tratados internacionais.

67 BASSIOUNI, M. Cherif. Introduction to Intenational Criminal Law..., pp. 142-143 usque 150-216.

68 Mormente porque na literatura em Direito Penal Internacional não existe um critério unívoco para se compreender o que sejam e quais são os crimes internacionais. "The writings of scholars are uncertain, if not tenuous, as to what they deem to be the criteria justifying the stablishment of crimes under international law". BASSIOUNI, Introduction to International Criminal Law..., p. 142. dão e tráfico de pessoas humanas;

- Tortura e outras formas de tratamento cruel, desumano ou degradante ou punição;

- Experimentação humana ilegal;

- Desaparecimento forçado e execuções extrajudiciais;

- Mercenarismo.

C) Proteção a interesses humanos associados a outros interesses internacionalmente associados

- Pirataria e atentados contra a segurança da navegação marítima e a segurança das plataformas em alto mar;

- Tomada de reféns e atentados contra a segurança da segurança aérea;

- Ameaça e/ou o uso de força contra sujeitos internacionalmente protegidos e servidores das Nações Unidas;

- O sequestro de civis;

- Uso de explosivos;

- Financiamento do terrorismo;

- O uso ilegal dos meios de comunicação internacional, em especial correio;

\section{D) Proteção de interesses sociais e culturais}

- Tráfico ilícito de drogas e substâncias estupefacientes;

- Crime organizado;

- Destruição ou roubo de tesouros nacionais;

- Atos ilegais contra determinados interesses internacionalmente protegiso relacionados ao desenvolvimento;

- Tráfico internacional de material obsceno;

- Falsificação e contrafação;

- Interferência ilícita nos cabos submarinos internacionais;

- Corrupção e suborno de servidores públicos estrangeiros.

Embora não tenha sido citado por Bassiouni, o crime de lavagem de capitais toma parte nessa última classificação, posto que se constitui em ilícito internacional previsto em diversos Tratados Internacionais que 
regulamentam diversos crimes transnacionais de caráter econômico ${ }^{69}$. Como já afirmado em outro momento ${ }^{70}$ :

[...] o crime de lavagem de capitais é um delito previsto nas principais convenções internacionais pactuadas no sistema das Nações Unidas (doravante ONU) em matéria de Direito Penal - Tráfico de Entorpecentes, o Crime Organizado, Contra a Corrupção e Contra o Financiamento do Terrorismo-, no que resta evidenciado o seu caráter transnacional, conforme, aliás, é reconhecido na Exposição de Motivos da Lei 9613/1998 (Lei de Lavagem de Capitais), que se reporta expressamente ao cumprimento das obrigações internacionais assumidas pelo Estado brasileiro quanto à persecução desse delito.

Agora, para compreender este fenômeno da expansão do Direito Penal em matéria penal é importante relembrar que até 1815 o único crime reconhecido como de transcendência internacional era a pirataria, decorrente dita incriminação de normas consuetudinárias do Direito Internacional Geral. Somente em 1958 ocorreu a sua positivação internacional através da Convenção de Genebra sobre o Alto Mar, ex vi de seus artigos 18-19. O mesmo se repetiu com a aprovação da Convenção das Nações sobre o Direito do Mar, de 1982, que, em seus artigos 100-107, estabelece uma ampla regulação da matéria, assegurando a todos os Estados o poder-dever de apresamento de navios ou aeronaves envolvidos em atos de pirataria, remetendo a persecução penal à regulação nacional do Estado apresador.

No que concerne, doutro giro, à fragmentação, esta característica também se encontra presente como elemento constitutivo do Direito Penal Internacional. M. Cherif Bassiouni, ao analisar as 281 Convenções Internacionais que regulam, atualmente, a matéria, encontrou 931 elementos penais comuns, mas que, numa análise isolada, chegam a $2.810^{71}$. Essa variação conteudística é ocasionada pelo fato, nada banal no âmbito do Direito Internacional, de que:

69 Convenção contra o Tráfico Ilícito de Entorpecentes e Substâncias Psicotrópicas, ratificada pelo Brasil através do Decreto Legislativo n. 162/1991, Convenção das Nações Unidas contra o Crime Organizado Transnacional, ratificada pelo Brasil através do Decreto Legislativo n. 231/2003, Convenção das Nações Unidas contra Corrupção, ratificada pelo Brasil através do Decreto Legislativo n. 348/2008, Convenção Internacional para a Supressão do Financiamento do Terrorismo, ratificada pelo Brasil através do Decreto Legislativo n. 769/2005.

70 DE OLIVEIRA, A internacionalização do direito penal: uma aproximação a partir do crime de lavagem de capitais..., pp. 130-163.

71 BASSIOUNI, Introduction to International Criminal Law..., p. 145.
A) O Direito Penal Internacional não é codificado ${ }^{72}$, fato este que gerou uma ausência de uniformização na regulação internacional da matéria ${ }^{73}$, mormente se se considerar que ele

B) tem sido criado ao longo de vários anos - mais especificamente, desde 1815 -, sem que haja uma política criminal, pelo que determinados campos passaram por um processo de aperfeiçoamento mais evidente ( $v . g$., os crimes internacionais próprios pós o ETPI), enquanto outros não. Contudo, todos eles ainda estão submetidos ao humor dos atores internacionais ${ }^{74}$, seja no que concerne à sua criação - e.g. a prevalência do interesse do Estado em detrimento da adoção de uma regulação comum -, seja no que diz respeito à sua execução ${ }^{75}$;

C) Demais, diferentemente do que ocorre no âmbito de grande parte dos Estados, o processo legislativo internacional ainda é conformado pelas fontes que lhe são inerentes, isto é, os tratados internacionais, os costumes internacionais e os princípios gerais do direito, do que segue a circunstância de que a contínua formação do Direito Penal Internacional é no mínimo "[...] aleatório e, pode-se mesmo dizer, incoerente". ${ }^{76}$

Se a formação normativa do Direito Penal Internacional está submetida a essa "incoerência", o que de per se é suficiente para comprovar o fenômeno da diferenciação funcional, o conflito real entre os sistemas de solução de controvérsia vis-à-vis — que é o traço mais marcante desse fenômeno normativo — também se faz presente.

O exemplo mais significativo nesse sentido pode ser extraído da controvérsia que se manifestou no que toca ao crime de genocídio no contexto das guerras na Ex-

72 BASSIOUNI, Introduction to International Criminal Law..., p. 141.

73 BASSIOUNI, Introduction to Internacional Criminal Law, p. 219.

74 BASSIOUNI, Introduction to International Criminal Law, pp. 139-141.

75 Sobre o tópico, no qual entra em questão o conflito entre a concretização do Direito Internacional em geral, e do Direito Penal Internacional em particular, e a realpolitik, BASSIOUNI, M. Cherif. The perennial conflict between international criminal justice and realpolitik...; DANNER, Allison Marsten, SIMMONS, Beth. Sovereignty costs, credible commitments, and the International Criminal Court. Disponível em www.law.yale.edu/documents/ pdf/Faculty/DannerSimmons07.pdf, acessado em 10/06/2013, às 17:00:00; AMBOS, Kai. Processando crimes internacionais em nível nacional e internacional: justiça x Realpolitik, in JAPIASSÚ, Carlos E. Adriano (Org). Direito Penal Internacional estrangeiro e comparado: Rio de Janeiro: Lumen Juris, 2007, pp. 86-88.

76 BASSIOUNI, Introduction to International Criminal Law..., p. 253. 


\section{-Iugoslávia ${ }^{77}$.}

A constituição do Tribunal Penal Internacional para a Ex-Iugoslávia por Resolução do CSONU foi precedido pelo trabalho de uma Comissão de Expertos composta por Frits Kalshoven - Presidente, M. Cherif Bassiouni (Egito), William J. Fenrik (Canadá), Kéba M’baye (Senegal) e Torkel Opsahl (Noruega) ${ }^{78}$, cujos trabalhos sofreram inúmeros percalços para serem levados a termo, mormente em razão do conflito político que se estabeleceu entre os grupos inseridos ideologicamente naquilo que se pode identificar como "mudanças políticas no liberalismo jurídico" ("change politics of liberal legalism") ${ }^{79}$ e os defensores do modelo tradicional de solução diplomática ${ }^{80}$. Se, para aqueles, a função política do Direito Penal Internacional é a de "[...] remover do negociador político a capacidade de jogar a carta da justiça" " to remove from the political negotiator the ability to play the car of justice") ${ }^{81}$, para estes, a solução negociada diplomaticamente, representada, no caso, pelo Plano de Paz Owen-Vance ${ }^{82}$.

77 A rigor, a Guerra da Ex-Iugoslávia ou Guerra dos Balcãs, se constituiu em várias guerras civis envolvendo, de um lado, a luta pela independência de comunidades políticas com orientação étnica, e de outro lado, a tentativa de a República da Sérvia, conformada etnicamente pela maior etnia, em exercer o domínio sobre parte do território mediante a prática daquilo que se cunhou como limpeza étnica. Os diversos conflitos se iniciaram com a proclamação da independência pela Eslovênia, em 1991, e seguiu, em diversos conflitos até a independência da Macedônia, em 2001. As diversas guerras podem ser assim sistematizadas: 1) guerra da independência da Eslovênia (1991); 2) guerra da independência da Croácia (1991-1995); 3) guerra da Bósnia (1992-1995); 4) guerra do Kosovo (1996-1999); 5) conflito no sul da Sérvia (2000-2001); 6) conflito na Macedônia (2001). A OTAN, em cumprimento das Resoluções 713 (1991) e 757 (1992) do CSONU, executou pela primeira vez na história, as seguintes intervenções internacionais de caráter humanitário: 1) Operação Força Deliberada (contra a República Srpska, 19951996) e 2) Operação Força Aliada (contra a Iugoslávia, 1999).

78 Esta Comissão foi instituída pelo CSONU através da Resolução n. 780, de 06 de outubro de 1992. JAPIASSÚ, O Tribunal Penal Internacional..., pp. 95-96.

79 HAGAN, Justice in the Balkans..., p. 35-38.

80 Esse conflito é muito bem retratado no "embate" discursivo havido entre M. Cherif Bassiouni e o diplomata inglês Lord David Owen a respeito das investigações então feitas pela Comissão de Expertos em Vukovar, fatos que estes envolvidos na realização da “[...] exumação de duas centenas de ex-pacientes levados em novembro de 1991 do hospital da cidade croata de Vukovar [...]" e “[...] transportados para uma fazenda próxima a Ovcara, onde eles foram mortos e enterrados em foças coletivas. Vukovar foi uma das primeiras cidades da antiga Iugoslávia a ser vitimadas pela limpeza étnica sérvia" (grifamos). HAGAN, Justice in the Balkans..., pp. 34-35.

81 A expressão é de M. Cherif Bassiouni. HAGAN, Justice in the Balkans..., p. 35.

82 Em síntese, o Plano de Paz Owen-Vance propunha a pacifi-
Nada obstante, tendo a Comissão de Expertos terminado o trabalho de investigação e o apresentado para o $\mathrm{CSONU}^{83}$, restou comprovado tanto em dito relatório, como nos relatórios preliminares de 09 de fevereiro de $1993^{84}$ e de 05 de outubro de $1993^{85}$, que, no curso das diversas guerras havidas na Ex-Iugoslávia, os lados da refrega praticaram, de forma sistemática, crimes de guerra, crimes contra a humanidade e genocídio, razão pela qual o EICTY, em seus artigos 2 a 5 estabeleceu a competência ratione materiae do ICTY para a persecução dos autores desses crimes ${ }^{86}$.

Os crimes internacionais próprios exigem, para a sua tipicidade, a comprovação de que tenham sido praticados no contexto daquilo que se denomina de macrocriminalidade política ${ }^{87}$, vale dizer, que os crimes praticados tenham sido praticados a partir de uma decisão política estatal dirigida, e.g., ao genocídio, à limpeza étnica, à violação sistemática das normas do direito humanitário etc ${ }^{88}$, e somente isso justifica, à luz do Direito Internacio-

cação do conflito mediante a criação unidades políticas étnicas o que redundou, como consequência, a intensificação da prática do genocídio entre as etnias envolvidas, objetivando o fortalecimento de suas respectivas posições e domínios antes da divisão. LEROUXMARTIN, Phillipe. "Lições sobre a negociação da Bósnia" ESTADÃO, disponível em http://internacional.estadao.com.br/noticias/geral,licoes-da-negociacao-sobre-a-bosnia,1121639, acessado em 20/02/15, às 10:00.

83 O relatório foi submetido ao CSONU através da Carta do Secretário Geral da ONU ao Presidente do CSONU de 24 de maio de 1994. Disponível em http://www.icty.org/x/file/About/OTP/ un_commission_of_experts_report1994_en.pdf, acessado em 20/01/2010, às 15:00.

84 A evidência da ocorrência desses crimes era tão significativa que o CSONU não aguardou a conclusão dos trabalhos da Comissão, tendo resolvido, já com a apresentação do primeiro relatório preliminar de 09 de fevereiro de 1993 pela criação do ICTY. JAPIASSÚ, O Tribunal Penal Internacional..., p. 96.

85 JAPIASSÚ, O Tribunal Penal Internacional..., p. 96.

86 Uma questão muito importantes na tipificação dos crimes de competência do ICTY foi o fato de o seu Estatuto ter arrolado, pela primeira vez, o estupro entre os crimes contra a humanidade (art. 5, "g"), no que foi seguido pelo ETPIR (art. 3, "g") e o ETPI (art. 7, "g"). Sobre o tema, HAGAN, Justice in the Balkans..., pp. 51-53. 87 AMBOS, A parte geral do Direito Penal Internacional..., pp. 54-59.

88 Nesse sentido, BASSIOUNI, M. Cherif. Crimes against humanity..., p. 14 et seq; sob uma perspectiva criminológica, KELMAN, Herbert C. The policy context of international crimes, in NOLLKAEMPER, André, DER WILT, Harmen van. System criminality in international law, Cambridge: Cambridge University Press, 2009, pp. 26-41. O TPIIug, no caso Popovic et all (caso Srebrenica), consignou esta exigência de forma muito clara: "Furthermore, according to Professor Schabas, the language of the Elements of Crimes of the ICC Statute ("ICC Elements of Crimes") - requiring for genocide that "the conduct took place in the context of a manifest pattern of similar conduct directed against that group 
nal Penal, a legitimidade tanto do indiciamento de dirigentes políticos ${ }^{89}$, como também a condenação de várias pessoas pelo cometimento de genocídio pelo Tribunal.

Entretanto, a CIJ, em duas ocasiões em que julgou a ocorrência de violação às normas da Convenção para a Prevenção e Repressão do Crime de Genocídio de 1948, reconheceu que, muito embora seja incontestável que nos Conflitos dos Balcãs tenham sido praticados atos de genocídio, os Estados envolvidos não poderiam ser responsabilizados internacionalmente, porquanto não restou comprovado o elemento "state policy".

Assim, no caso Bósnia e Hergovina vs Sérvia e Montenegro $^{90}$, a CIJ rechaçou o pedido de condenação internacional da Sérvia por violação à Convenção sobre Genocídio sob o argumento de que esse Estado não foi, direta nem indiretamente, responsável pelo genocídio praticado no território da Bósnia-Herzegovina. A responsabilidade internacional, entretanto, restou caracterizada na forma omissiva, na medida em que as tropas sérvias não haviam impedido, quando possível, a prática de atos de genocídio por grupos paramilitares, nem o Estado cooperado internacionalmente com o ICTY para exercer a persecução criminal de seus autores. Somente o então Vice-Presidente da CIJ, Awn Shawkat Al-Khasawneh, em seu voto dissidente, consignou que “[...] o envolvimento da Sérvia, como autor principal ou cumplice, no genocídio ocorrido em Srebrenica é confirmada pela evidência maciça e convincente".

Já no caso Croácia vs Sérvia ${ }^{91}$, em que ambos os

or was conduct that could itself effect such destruction" - implicitly supports the State policy requirement, thus rejecting the lone génocidaire theory. Professor Schabas also contends the additional requirement of "manifest pattern" spelled out in the ICC Elements of Crimes "is strong evidence that it is implicit in customary international law"', ICTY. Trial Chamber II. Case Prosecutor vs POPOVIC, Vujadin et all (Srebrenica Case), disponível em http://www. icty.org/x/cases/popovic/tjug/en/100610judgement.pdf, acessado em 10/01/2012, às 14:45, p. 335.

89 ICTY. Apell Chamber. Case Prosecutor vs Radovan Karadzic, disponível em http://www.icty.org/x/cases/karadzic/acjug/ en/130711_judgement_rule98bis.pdf , acessado em 10/01/2012, às 14:30; ICTY. Apell Chamber. Case Prosecutor vs Ratko Mladic, disponível em http://www.icty.org/x/cases/mladic/tjug/en/140415summary.pdf, acessado em 30/06/2014, às 23:00.

90 CIJ. Case concerning application of the Convention on the Prevention and Punishment of the Crime of Genocide (Bosnia and Herzegovina vs. Serbia and Montenegro), judgement of 26 February of 2007, disponível em http://www.icj-cij.org/docket/ files/91/13685.pdf, acessado em 20/01/2012, às 15:35.

91 CIJ. Case concerning application of the Convention on the Prevention and Punishment of the Crime of Genocide (Croatia v. Serbia), judgement of 3 February 2015, disponível em http://www.
Estados buscaram a imputação de responsabilidade internacional pela violação à Convenção sobre Genocídio, a CIJ decidiu que, embora tenham ocorridos fatos gravíssimos caracterizados como genocídio e crimes contra a humanidade vis-à-vis, não restou comprovado o "state policy" para a tipificação do genocídio, tendo a Corte concitado os Estados a continuarem na cooperação internacional para apurar as responsabilidades dos autores de crimes e o destino das vítimas ainda desaparecidas, bem como reparar adequadamente as vítimas e seus herdeiros, além de buscarem a consolidação da paz regional.

Essa contradição - a constituição de um tribunal penal internacional com competência para a persecução dos autores de genocídio, o que pressupõe, como já dito, o elemento da decisão política —, e a "absolvição" pela CIJ dos Estados envolvidos no que concerne à obrigação internacional decorrente da Convenção sobre Genocídio, mais do que um problema, meramente, acadêmica, põe em questão um dos elementos fundamentais do Direito Penal Internacional em matéria de core crimes, a saber, a relação essencial entre responsabilidade estatal e responsabilidade individual ${ }^{92}$.

Assim, não resta qualquer dúvida quanto ao caráter expansivo e fragmentário da jurisdição penal internacional, sendo que estas duas características podem ser interpretadas a partir de dois paradigmas distintos.

O primeiro seria a assunção de uma postura derrotista, no sentido de que, para reportar àquela concepção jurídico-liberal, os atores estatais ainda têm um poder ilimitado de "jogar as cartas da justiça” em suas respectivas relações de poder e interesses internacionais; a segunda a de uma postura idealista, mas não o idealismo transcendental que não logra tocar os pés no chão, mas aquele que, com um olho na realidade histórica e outro na luta pela consolidação da justiça internacional, logra perceber, dialeticamente, os avanços e retrocessos a que qualquer projeto politico está submetido. Mais explicitamente, reconhecer que ${ }^{93}$

[...] estamos desenvolvendo gradualmente o conceito do Direito a serviço da humanidade.

icj-cij.org $/$ docket $/$ index.php?p1 $=3 \& p 2=3 \& \mathrm{k}=73 \&$ case $=118 \&$ cod $\mathrm{e}=$ cry\&p3 $=4$, acessado em 01/03/2015, às 12:30.

92 BONAFE, Beatrice I. The relationship between state and individual responsability for international crimes, Leiden: Martinus Nijhoff, 2009, pp. 21 et seq.

93 JENKS, citado por PASTOS RIDRUEJO, Curso de derecho internacional publico..., p. 34. 
Existem provas amplas destas tendências em cada página da história contemporânea. Elas mostram de maneira concludente que somente sendo idealistas impenitentes podemos ser realistas para a solução dos problemas atuais e aliviar nossos descontentamentos presentes.

O passo decisivo, entretanto, não está na infirmação das jurisdições nacionais, mas, antes, na consolidação dos processos de cooperação internacional em matéria penal, mormente no momento atual em que vários Estados africanos deram início aos processos de denúncia do ETPI sob os mais variados argumentos, em especial a acusação o da "africanização" do TPI.

\section{Considerações finais}

Hannah Arendt, em seu livro A Condição Humana, afirma que, entre os gregos, a partir do momento em que se constituíram as polei, ao homem livre era dado duas ordens de vivência. A oikia, a casa, e a polis, a cidade. Naquele vivia-se o que era próprio a qualquer pessoa (idion), e nessa aquilo que era comum (koinon) a todos os homens livres: a vida livre e igualitária propiciada pela política $^{94}$.

Mutatis mutandi, aos Estados também se assegura, pelo Direito Internacional, uma dupla existência: uma interna e própria, que é o seu autogoverno livre e desimpedido, e outra, igualitária e comum, que é a vida na Sociedade Internacional.

Que as palavras não nos enganem. De idion derivou idiota, que para os gregos seriam aqueles homens incapazes de transcenderem a vida do lar e viverem a vida comum da polis.

Nesse sentido, qualquer tentativa de enfrentamento da macrocriminalidade internacional pelo Estado, e não pelos Estados, será, por definição, idiota, isto é, infrutífera por não se perceber que somente a execução dos programas internacionais de cooperação internacional em matéria penal poderá ensejar o seu enfrentamento, ou como dito desde já há algum tempo por Celso D. de Mello, "A luta contra o crime somente será eficaz com a cooperação internacional" 95 . Mais concretamente, e

94 ARENDT, Hannah. A condição humana, trd. Roberto Raposo, 10 ed., Rio de Janeiro: Forense Universitária, 2005, pp. 32-35. 95 MELLO, Curso de direito internacional público, t. II, 11 ed., Rio de Janeiro: Renovar, 2002, p. 976. para ficarmos no topos idealismo-realismo, que sejamos realistas e tentemos o impossível.

\section{REFERÊNCIAS BIBLIOGRÁFICAS}

AGAMBEN, Giorgio. Nota introdutória sobre o conceito de democracia, trd Marcus Vinícius Xavier de Oliveira, in DANNER, Fernando, DANNER, Leno, KONZEN, Paulo Roberto. Democracia, política, representação: ensaios filosóficos, Porto Alegre, FI, 2014, pp. 11-15.

AKERURST, Michael, MALANCZUK, Peter (org.). Akehurt's modern introduction to internacional law, 17 ed., New York: Routledge, 1997.

AMBOS, Kai, KARAYAN, Monica. Impunidad y derecho penal internacional, 2 ed., Buenos Aires: Ad Hoc, 1999.

AMBOS, Kai. La parte general del derecho penal internacional: bases para una elaboración dogmática, trd. Ezequiel Malarino, Berlin/Montvideo: KonradAdenauer Stiftung, 2005.

AMBOS, Kai. Processando crimes internacionais em nível nacional e internacional: justiça x Realpolitik, in JAPIASSÚ, Carlos E. Adriano (Org). Direito Penal Internacional estrangeiro e comparado: Rio de Janeiro: Lumen Juris, 2007.

ARENDT, Hannah. A condição humana, trd. Roberto Raposo, 10 ed., Rio de Janeiro: Forense Universitária, 2005.

ÁVILA, Humberto. Teorias dos princípios: da definição à aplicação dos princípios jurídicos, São Paulo: Malheiros, 2003.

BASSIOUNI, M. Cherif. Universal jurisdiction for international crimes: historical perspectives and contemporary practice, Virginia Journal of International Law, n. 42, v. 81, fall 2001.

BASSIOUNI, M. Cherif. The perenial conflict between international criminal justice and realpolitik, in Miller Lecture, Georgia State College of Law, 2006. Disponível em www.law.gsu.edu/Miller_Lecture/2006/ MillerLecture-S06-BassiouniDraft.pdf, acessado em 30/10/2011.

BASSIOUNI, M. Cherif. Crimes against humani- 
ty: historical evolution and contemporary application, Cambridge: Cambridge University Press, 2011.

BASSIOUNI, M. Cherif. Introduction to international criminal law, 2th edition, Leiden: Martinus Nijhoff Publishers, 2013.

BAZELAIRE, Jean-Paul, CRETIN, Thierry. A justiça penal internacional: sua evolução, seu futuro de $\mathrm{Nu}$ remberg a Haia, trd. Luciana P. Venâncio, Bauru: Manole, 2004.

BERMAN, Sir Franklin. Jurisdiction: the State, in CAPPSS, Patrick, EVANS, Malcolm, KONSTADINIDIS, Stratos. Asserting jurisdiction: international ans european legal approaches, Portland: Hart Publishing, 2003.

BOBBIO, Norberto, POLITO, Pietro (Org.). O terceiro ausente: ensaios e discursos sobre a guerra e a paz, trd. Daniela Versiani, São Paulo: Manole, 2009.

BODINO, Juan. Los seis libros de la Republica, t. I, trd. Gaspar de A. Isunza, Madri: Centro de Estudios Constitucionales, 1992.

BONAFE, Beatrice I. The relationship between state and individual responsability for international crimes, Leiden: Martinus Nijhoff, 2009.

CANARIS, Claus-Wilhelm. Pensamento sistemático e conceito de sistema na Ciência do Direito, 2 ed., trad. A. Menezes Cordeiro, Lisboa: Fundação Calouste Gulbenkian, 1996.

CASSESSE, Antonio. Lineamenti di diritto Internazionale penale I: diritto sustanziale, Bolgna: Il Molino, 2005.

CRUVELLIER, Thierrry. Court of remorse: inside the International Criminal Court for Rwanda, trd. Chari Voss, Madison: University of Wisconsin Press, 2006.

DE OLIVEIRA, Marcus Vinícius Xavier de Oliveira. Direito penal internacional, estado constitucional e o problema da mitigação da soberania na persecução dos crimes internacionais próprios, in DE OLIVEIRA, Marcus Vinícius Xavier. Temas escolhidos sobre a internacionalização do direito penal, Porto Alegre: FI, 2015, pp. 19-88.

DE OLIVEIRA, Marcus Vinícius Xavier. A internacionalização do direito penal: uma aproximação a partir do crime de lavagem de capitais, in DE OLIVEIRA, Marcus Vinícius Xavier. Temas escolhidos sobre a internacionalização do direito penal, Porto Alegre: FI, 2015, pp. 130-163.

DE OLIVEIRA, Marcus Vinícius Xavier. A internacionalização do direito da execução penal: em que(quais) sentido(s)?, in DE OLIVEIRA, Marcus Vinícius Xavier. Temas escolhidos sobre a internacionalização do direito penal, Porto Alegre: Fi, 2014, pp. 274-306.

DE VAT'TEL, Emer. O direito das gentes, trd. Vicente Marotta Rangel, Brasília: IPRI/Editora da UNB, 2004.

DELMAS-MARTY, Mireille.. Trois défis pour un droit mondial, Paris: Éditions du Seuil, 1998.

DÓRIA, A. Sampaio. Curso de Direito Constitucional (Os Direitos do Homem), t. 1, 2 ed., São Paulo: Cia Editora Nacional, 1946.

FERRAJOLI, Luigi. Direito e razão: teoria do garantismo penal, 2 ed., trd. Juarez Tavares et al., São Paulo: RT, 2006.

FERRAZ JR, Tércio Sampaio. Introdução ao estudo direito: técnica decisão dominação, 3 ed., São Paulo: Atlas, 2001.

GIL-GIL, Alicia. Derecho penal internacional, Madri: Tecnos, 1999.

GOUVEIA, Jorge Bacelar. Manual de Direito Internacional público, Rio de Janeiro: Renovar, 2005.

GROTIUS, Hugo. O direito da guerra e da paz, vol. I, trd. Ciro Mioranza, Ijuí: Editora Unijui, 2004.

GUGGENHEIM, Paul. Contribution a l'historie des sources du Droit des Gens, RCADI, vol. 94 (1958-II).

HÄBERLE, Peter, KOTZUR, Markus. De la soberanía al derecho constitucional común: palabras clave para un diálogo europeu-latinoamericano, trad. Héctor Fix-Fierro, Cuidad de Mexico: UNAM, 2003.

HÄBERLE, Peter. E1 Estado constitucional, trad. Héctor Fix-Fierro, Cuidad de Mexico: UNAM, 2003.

HÄBERLE, Peter. O Estado Constitucional Cooperativo, trad. Marcos A. Maliska e Elisete Antoniuk, Rio de Janeiro: Renovar, 2007.

HAGAN, John. Justice in the Balcans: prosecuting war crimes in the Hague Tribunal, Chicago: Chicago University Press, 2003.

JANKOV, Fernanda F. F. Direito Internacional penal: 
mecanismos de implementação do Tribunal Penal Internacional, São Paulo: Saraiva, 2009.

JAPIASSÚ, Carlos Eduardo Adriano. O Tribunal Penal Internacional: a internacionalização do Direito Penal, Rio de Janeiro: Lumen Juris, 2004.

KELMAN, Herbert C. The policy context of international crimes, in NOLLKAEMPER, André, DER WILT, Harmen van. System criminality in international law, Cambridge: Cambridge University Press, 2009.

KELSEN, Hans. A paz garantida pela responsabilização individual por violações do Direito Internacional, in A paz pelo direito, trad. Lenita A. do Nascimento, São Paulo: Martins Fontes, 2011.

KELSEN, Hans. Will the Judgment in the Nuremberg Trial Constitute a Precedent in International Law?, International Law Quaterly, v. 1, n. 2, summer 1947.

KLABBERS, Jan. An introduction to international institutional Law, Cambridge: Cambridge University Press, 2002.

KLEINEN, Thomas. Konstitutionalisierung im Völkerrecht: einer idealistichen Völkerrechtslehre, Heildeberg: Springer, 2012.

KOSKENNIEMI, Martti. Fragmentation of international law: difficulties arising from the diversification and the expansion of International Law - Report of the Study Group of the International Law Commission. INTERNATIONAL LAW COMMISSION, Fifty-eighth session, Geneva, 1 May-9 June and 3 July11 August 2006.

KOTZUR, Markus. A Soberania Hoje. Palavras-Chave para um Diálogo Europeu Latino-Americano Sobre um Atributo do Estado Constitucional Moderno, trd. Marcus V. X. de Oliveira e Gabriel G. de Godói, Revista Quaestio Iuris, Rio de Janeiro, 2012, pp. 1-19.

LEROUX-MARTIN, Phillipe. "Lições sobre a negociação da Bósnia” ESTADÃO, disponível em http:// internacional.estadao.com.br/noticias/geral,licoesda-negociacao-sobre-a-bosnia,1121639, acessado em 20/02/15, às 10:00.

LOCK, Grahame. Ringing the changes: mutations in the idea of political change, in KERSBERGEN, Kees van et all (Orgs.). Expansion and fragmentation: internationalization, political change and the transformation of the Nation State, Amsterdam: Amsterdam Uni- versity Press, 1999.

MELLO, Celso D. de Albuquerque. Curso de Direito Internacional Público, t. I, 13 ed., Rio de Janeiro: Renovar, 2001.

MELLO, Celso D. de Albuquerque. Curso de Direito Internacional Público, t. II, 13 ed., Rio de Janeiro: Renovar, 2002.

ONU. Carta do Secretário Geral da ONU ao Presidente do CSONU de 24 de maio de 1994. Disponível em http://www.icty.org/x/file/About/OTP/un_commission_of_experts_report1994_en.pdf, acessado em 20/01/2010, às 15:00.

ONU. "Principles of International Law Recognized in the Charter of the Nürnberg Tribunal and in the Judgement of the Tribunal", Yearbook of the International Law Comission, 1950, vol. II.

PASTOR RIDRUEJO, José Antonio. Curso de derecho internacional público y organizaciones internacionales, 18 ed., Madri: Tecnos, 2014.

Regulamento do TPI sobre os elementos dos crimes já revisado, disponível em http://www. icc-cpi.int/NR/rdonlyres/A851490E-65144E 91 -BD 45-AD9A216CF47E/283786/ElementsOfCrimesSPAWeb.pdf, acessado em 20/08/2011, às 14:31:00.

SCHABAS, William A. An introduction to the International Criminal Court, 4 ed., Cambridge: Cambridge University Press, 2011.

SCHLÜTTER, Birgit. Developments in customary international law: theory and the practice of the International Court of Justice and the International ad hoc Criminal Tribunals for Rwanda and Yugoslavia, Leiden: Martinus Nijhoff, 2010.

SHAW, Malcolm. International law, $6^{\text {th }}$ ed., Cambridge: Cambridge University Press, 2008.

VARELLA, Marcelo D., de Oliveira, Vitor Eduardo Tavares. "Da unidade à fragmentação do Direito Internacional: o caso Mox Plant", Revista da Faculdade de Direito da UFMG, Belo Horizonte, n. 54, jan/jun 2009.

WEIL, Prosper. Le droit international en quête de son identité, Cours général de droit international public, RCAD vol. 237/1992, pp. 09-370.

WERLE, Gerhardt. Principles of international cri- 
minal law, $2^{\text {th }}$ edition, Hague: T M C Asser Publishers, 2009.

WITTGENSTEIN, Ludwig. Tractatus logico-philosophicus, Londres: Kegan Paul, Trench, Trubner \& Co, 1922.

\section{Decisões Judicials}

CIJ. Case concerning application of the Convention on the Prevention and Punishment of the Crime of Genocide (Bosnia and Herzegovina vs. Serbia and Montenegro), judgement of 26 February of 2007, disponível em http://www.icj-cij.org/docket/files/91/13685.pdf, acessado em 20/01/2012, às 15:35.

CIJ. Case concerning application of the Convention on the Prevention and Punishment of the Crime of
Genocide (Croatia v. Serbia), judgement of 3 February 2015, disponível em http://www.icj-cij.org/docket/ index.php?p1 $=3 \& \mathrm{p} 2=3 \& \mathrm{k}=73 \&$ case $=118 \& \operatorname{code}=$ cry \&p3=4, acessado em 01/03/2015, às 12:30.

ICTY. Apell Chamber. Case Prosecutor vs Radovan Karadzic, disponível em http://www.icty.org/x/cases/ karadzic/acjug/en/130711_judgement_rule98bis.pdf , acessado em 10/01/2012, às 14:30.

ICTY. Apell Chamber. Case Prosecutor vs Ratko Mladic, disponível em http://www.icty.org/x/cases/ mladic/tjug/en/140415-summary.pdf, acessado em 30/06/2014, às 23:00.

ICTY. Trial Chamber II. Case Prosecutor vs POPOVIC, Vujadin et all (Srebrenica Case), disponível em http://www.icty.org/x/cases/popovic/tjug/ en/100610judgement.pdf, acessado em 10/01/2012, às 14:45. 
Para publicar na Revista de Direito Internacional, acesse o endereço eletrônico www.rdi.uniceub.br ou www.brazilianjournal.org.

Observe as normas de publicação, para facilitar e agilizar o trabalho de edição. 